\title{
Article \\ Construction and Optimization of an Urban Ecological Security Pattern Based on Habitat Quality Assessment and the Minimum Cumulative Resistance Model in Shenzhen City, China
}

\author{
Yu-Zhe Zhang ${ }^{1}$, Zhi-Yun Jiang ${ }^{1, *}$, Yang-Yang $\mathrm{Li}^{1}{ }^{1}$, Zhi-Guang Yang ${ }^{2}{ }^{\mathbb{D}}$, Xiao-Hong Wang ${ }^{1}$ and Xian-Bing $\mathrm{Li}^{1}$ \\ 1 School of Geography, South China Normal University, Guangzhou 510631, China; \\ yzzhang@m.scnu.edu.cn (Y.-Z.Z.); 20182631017@m.scnu.edu.cn (Y.-Y.L.); \\ 20182621059@m.scnu.edu.cn (X.-H.W.); 20182631036@m.scnu.edu.cn (X.-B.L.) \\ 2 School of Natural Resources, Faculty of Geographical Science, Beijing Normal University, \\ Beijing 100875, China; zg_yang@mail.bnu.edu.cn \\ * Correspondence: zyjiang@scnu.edu.cn
}

Citation: Zhang, Y.-Z.; Jiang, Z.-Y.; Li, Y.-Y.; Yang, Z.-G.; Wang, X.-H.; Li, X.-B. Construction and Optimization of an Urban Ecological Security Pattern Based on Habitat Quality Assessment and the Minimum Cumulative Resistance Model in Shenzhen City, China. Forests 2021, 12, 847. https://doi.org/10.3390/ f12070847

Received: 11 May 2021

Accepted: 23 June 2021

Published: 26 June 2021

Publisher's Note: MDPI stays neutral with regard to jurisdictional claims in published maps and institutional affiliations.

Copyright: () 2021 by the authors. Licensee MDPI, Basel, Switzerland. This article is an open access article distributed under the terms and conditions of the Creative Commons Attribution (CC BY) license (https:// creativecommons.org/licenses/by/ $4.0 /)$.

\begin{abstract}
The rapid development of urbanization has caused many ecological issues and greatly threatened the sustainable development of human society. The construction of ecological security patterns (ESPs) offers an effective way to balance ecological conservation and urbanization. This study aimed to take the highly urbanized city of Shenzhen, China, as a study area to construct an urban ESP and put forward suggestions for the urban development of ecological security. Ecological sources were identified through the Habitat Quality module in the InVEST model, and ecological corridors, strategic ecological nodes, and stepping-stone patches were extracted based on the minimum cumulative resistance (MCR) model. These elements together constituted the ESP. In particular, with the results of the continuous decline in the overall habitat quality, this study identified ten ecological sources with superior habitat quality, mainly distributed in rural woodlands, in urban green land, and in forest park patches. An optimized pattern for Shenzhen City with one axis, three belts, and four zones is proposed, with the study area divided into an ecological preservation zone, a limited development zone, an optimized development zone, and a key development zone. Moreover, fortyfive ecological corridors were extracted and graded into three levels, presenting a spatial pattern of one axis and three belts. The appropriate widths of these ecological corridors were suggested to be between 30 and $60 \mathrm{~m}$ in Shenzhen City. In addition, we identified twenty-five ecological nodes, sixteen ecological fracture points, and sixteen stepping stones to improve the maintenance and construction of the ecological corridor network. More generally, this study demonstrates a scientific approach to identifying ESPs based on habitat quality, and can serve as a reference for the planning of urban ecological function regionalization.
\end{abstract}

Keywords: ecological security pattern; habitat quality; ecological security zoning; minimum cumulative resistance model; ecological corridor

\section{Introduction}

Natural habitats play an important role in maintaining biodiversity, regulating climate, and mitigating droughts and floods [1,2]. Global urban land cover is expected to increase by 1.2 million $\mathrm{km}^{2}$ between 2000 and 2030, and this will inevitably result in the loss of natural habitat [3]. For the global community, increased economic activity and competition for land have led to sustained encroachment on affected habitat areas [4], and economic welfare losses are linked to the concomitant fragmentation of habitats and loss in biodiversity [5]. Coordinating economic development and environmental protection has become a global challenge [6-8]. With rapid urbanization, the integrity of ecosystems in highly developed cities is under tremendous pressure [9]. With widespread concern about socioeconomic and ecological problems, ecological security has also become a focus in research on regional landscape ecology [10-12]. 
In response to the problem of urban ecological security, countries around the world have implemented technical schemes and planning strategies to protect the ecological environment. These include urban growth boundaries [13], environmental networks [14], and green infrastructure [15]. Ecological security patterns (ESPs) have gradually become essential in planning and management to coordinate economic development and ecological protection [16]. ESPs are commonly defined as spatial schemes comprising flexible and strategic elements, such as ecological source patches and corridors, with critical significance attached to the safeguarding and controlling of basic ecological processes $[17,18]$. In China, the agglomeration of urban populations and the expansion of construction land have led to the compression of ecological land [19]. ESPs ensure that this limited ecological land can maintain ecosystem security and health [20]. Current paradigms for ESPs include source recognition, resistance surface creation, and corridor identification [21]. These components are widely used in urban ecological construction [22,23].

Specifically, ecological sources serve important ecosystem service functions and play a decisive role in regional ecological processes and functions [24]. Ecological sources can be identified by two methods: large-scale habitat patches can be directly selected as source areas, such as nature reserves, scenic spots, large forestry, and farmland [17]; or an evaluation system can be used to identify the importance of patches, where ecological sensitivity, ecological function, landscape connectivity, and ecological risk are usually considered $[25,26]$. However, the identification of ecological sources was subjective to some extent in many previous studies. In this study, we propose a method based on habitat quality that involves simulating the sensitivity of different land-use types to impact factors, which is a quantitative assessment method to avoid subjectivity. Habitat quality is a measure used to characterize the optimal survival, reproduction, and energy flow conditions that source areas provide to organisms [27]. Based on the importance of patches in the assessment of habitat quality, source areas can be measured quantitatively and compared. Areas with superior habitats have more complete ecosystems and richer biodiversity, and thus they are prioritized as ecological sources [26].

The resistance surface better reflects the inherent linkages in ESPs because of the comprehensive consideration of the horizontal connection between land-use units [28]. Therefore, many studies construct resistance surfaces based on various methods, such as biological behavior resistance estimates, expert scoring, entropy weighing, and landscape development intensity indexing [29]. However, existing studies on constructing resistance surfaces are mostly based on expertise and overall ratings for certain land-use types. As such, the resulting landscape resistance surfaces are heavily dependent on grading factors $[30,31]$. At the same time, many previous studies ignore the internal differences in a given land-cover type and do not consider the impact of human activities on the ecological resistance coefficient [32]. Therefore, correcting a basic ecological resistance surface has become an important recent trend when constructing ecological resistance surfaces [20]. In this study, information from the habitat quality index is used to help estimate the landscape resistance of different units and to simulate the sensitivity of the landscape to threat factors. Good habitat quality promotes ecological processes and thus corresponds to low resistance.

A related concept is that of an ecological corridor, a key carrier that ensures the smooth flow of materials and energy between core patches of ecological sources. Ecological corridors generally exist in the ecosystem as linear landscape elements with ecological, cultural, and social functions [33,34]. Methods of identifying corridors are mainly based on the minimum cumulative resistance (MCR) model [35] and circuit theory [36]. At present, ecological corridors in ESPs are usually identified through a least-cost path analysis based on the ecological resistance surface $[37,38]$. Viewing land-use types as ecological resistance coefficients is one way to account for the high levels in heterogeneity of urban landscapes [39]. The MCR model comprehensively considers the horizontal connections between the land-use units [40] to reflect the internal organic connectivity of ESPs and the internal connectivity of ecological processes. The MCR model is practicable, expandable, and widely used [28]. On the basis of corridor identification, the relative importance of 
ecological corridors can be analyzed with the gravity model, which serves as an important basis for determining the priority protection order of the corridors and ecological nodes in ESPs [38].

Shenzhen City is a typical region in China that has undergone rapid urbanization since it was established as a special economic zone in 1980 [41]. Over the past 40 years, the gross domestic product (GDP) of Shenzhen has increased from approximately 42.2 million dollars in 1979 to 431.7 billion dollars in 2020, creating a miracle in the history of urbanization in the world [41]. However, continual land development has led to the fragmentation of its natural environment, threatening ecosystem connectivity, along with the rapid deterioration of ecosystem functions in recent decades [42]. The conflict between the development of construction land and the protection of ecological land has become a serious dilemma for urban land management, which is seeking spatial solutions for sustainable development [43]. In 2005, the municipal government designated the Basic Ecological Line to strictly control human land use and urban sprawl within specific boundaries [44]. This protection policy has been in place for 16 years, during which time the demand for construction land has increased. Some new solutions are needed that are more in line with the status quo and revisions of the Basic Ecological Line. Therefore, identifying important habitat patches and proposing sustainable urban ecological security patterns are essential for long-term human well-being. Based on the above, this study took Shenzhen City as the study area. We propose a feasible spatial scheme to alleviate this conflict through the construction of an urban ESP. The objectives are to (1) identify ecological sources based on habitat quality and distinguish ecological security zones; (2) extract potential corridors and grade their importance; and (3) put forward suggestions based on the ESP.

\section{Materials and Methods}

\subsection{Study Area and Data Sources}

Shenzhen City is situated in southern Guangdong Province, China $\left(22^{\circ} 26^{\prime}-22^{\circ} 51^{\prime}\right.$ $\mathrm{N}, 113^{\circ} 45^{\prime}-114^{\circ} 37^{\prime} \mathrm{E}$ ) (Figure 1). It is one of the central cities in the Guangdong-Hong Kong-Macau Greater Bay Area. The land area is about $1997.47 \mathrm{~km}^{2}$, with a total coastline of $260 \mathrm{~km}$. It is situated in a subtropical marine climate zone, with an average mean temperature of $22.4^{\circ} \mathrm{C}$ and an average mean annual precipitation of $1933 \mathrm{~mm}$ [45]. The main terrain types are low mountains, hills, tablelands, terraces, and plains. The soil types include red loam, paddy soil, coastal sandy land, and coastal saline swamp soil. The zonal vegetation types include tropical evergreen monsoon forests and subtropical seasonal evergreen broad-leaved forests [43]. There are 509 species of terrestrial wild animals, including 31 amphibians, 76 reptiles, 366 birds, and 36 mammals, with 83 first- or second-class key animal species under state protection and 55 species under provincial protection.

The data used in this study included the following main components: administrative boundary vector data for Shenzhen City; land-use-type raster data; road network vector data from 2000, 2010, and 2020; Landsat 8 OLI_TIRS remote sensing image data from 2020; and vector data of the residential areas and water areas. 

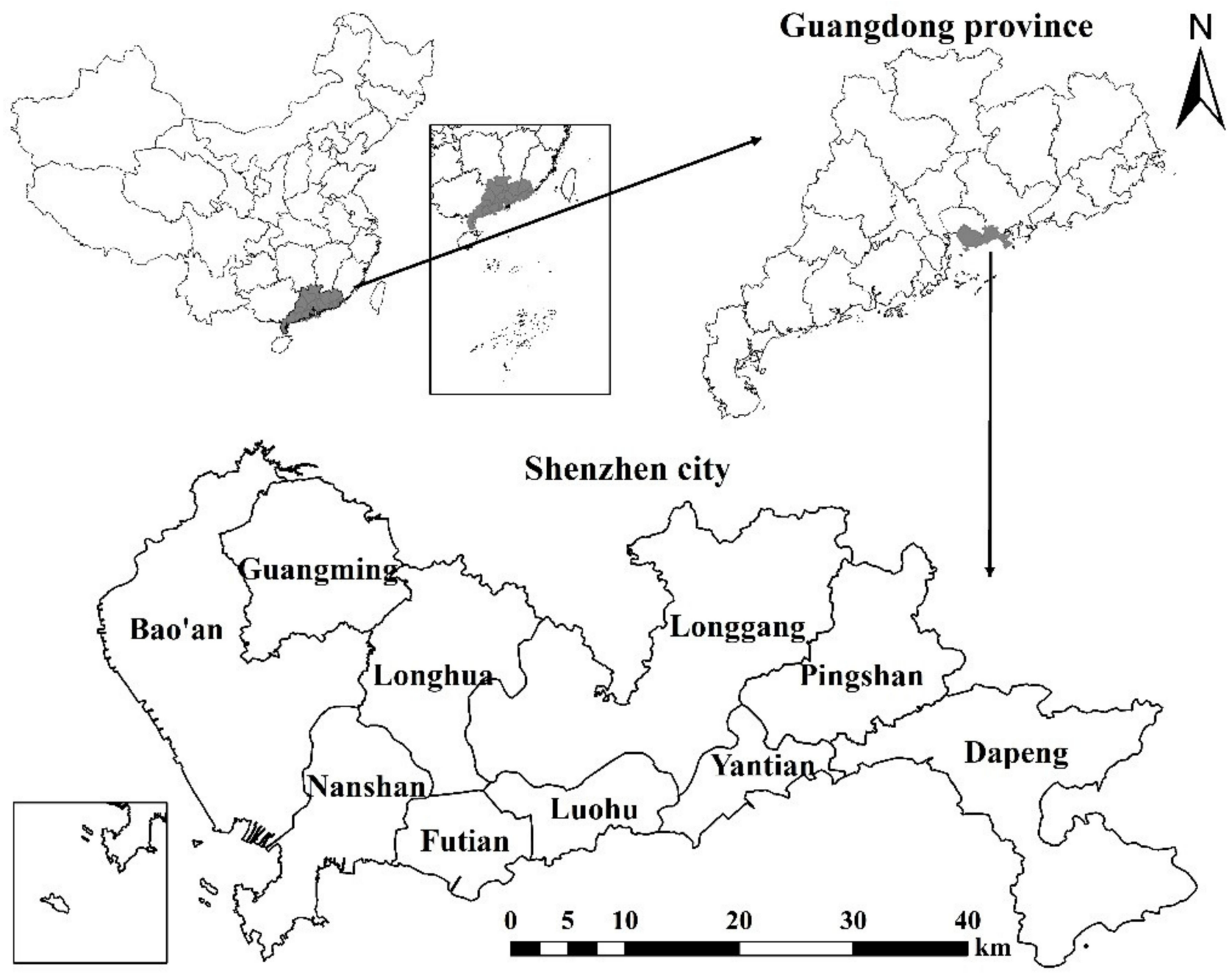

Figure 1. Location of Shenzhen City.

Among them, the administrative boundary data, residential data, and water area data were derived from the Resources and Environmental Science Data Center, Chinese Academy of Sciences (http: / / www.resdc.cn/, accessed on 26 January 2021). The land-use-type data were downloaded from the GLOBELAND30 website (http:/ / www.globallandcover.com/, accessed on 26 January 2021) and classified into eight categories: cultivated land, forest, grassland, shrub land, water areas, built areas, bare land, and sea areas. The remote sensing image data were sourced from the geospatial data cloud site (http:/ /www.gscloud.cn/, accessed on 27 January 2021), which was used to calculate the normalized vegetation index (NDVI) of the study area. The road network data were extracted from the OpenStreetMap website (https:/ / www.openstreetmap.org/, accessed on 28 January 2021) and the Peking University Geographic Data Platform (https:/ / geodata.pku.edu.cn/, accessed on 28 January 2021).

The schematic methodology is shown in Figure 2. Land-use data were divided into ecological landscapes and threat factors, with the details in Section 2.2. The Integrated Valuation of Ecosystem Services and Trade-offs (InVEST) model, a suite of open-source software mode that runs in the gridded map at an average annual time step, requiring relatively low data and expertise, has been widely used for assessing the impacts of landuse change on multiple ecosystem services [23,46]. We used the InVEST model to select the ecological sources with superior habitat quality. According to the habitat quality index, a resistance factor system was constructed. The MCR model was used to obtain the minimum cumulative resistance surface and to extract the ecological corridors. Ecological security 
zones were identified using a resistance threshold. Finally, ecological strategic nodes and stepping-stone patches were extracted to complete the construction of the ESP.

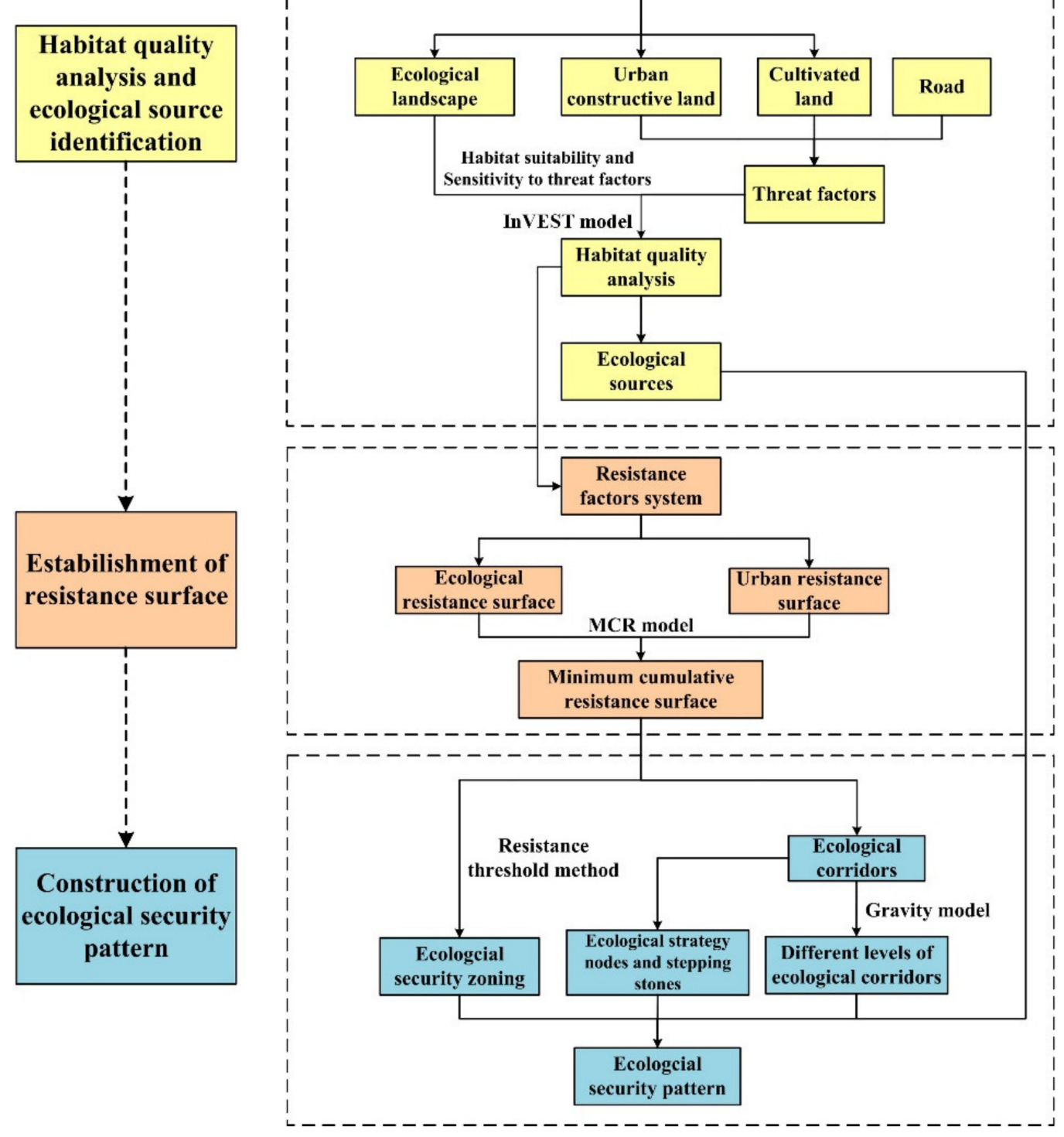

Figure 2. Flowchart of the analysis and research procedures in this study.

\subsection{Assessment of Habitat Quality and Source Identification}

The habitat quality index is the result of a comprehensive evaluation of the suitability and degradation of various habitat types in the region. This evaluation reflects the fragmentation of regional habitat patches and their resistance to various threat factors. The closer the value is to 1 , the better the habitat quality is, the more complete the ecosystem is, and the more conducive it is to the maintenance of biodiversity. In this study, the spatial distribution of habitat quality was obtained using the Habitat Quality module of the InVEST model, which combines the sensitivity of landscape types with the intensity of external threats. The module can thus be used to evaluate the maintenance of biodiversity [47]. This is done by quantifying the intensity of external threats and the sensitivity of various habitats to those threats. Four basic data inputs are needed to perform this model: (1) 
land-use-type raster data; (2) threat factors, including cultivated land, urban constructive land, and roads; (3) the sensitivity of the land-use types to habitat threat factors; and (4) a half-saturation constant value of the parameter $\mathrm{k}$ in Equation (1). More detail can be seen in the user's guide of the InVEST Model [47]. According to the needs of the model and the actual situation of the study area, the relevant attributes of the threat factors were set as shown in Table 1, and the relevant attributes of the land-use types were set as shown in Table 2.

Table 1. Attributes of the threat factors.

\begin{tabular}{cccc}
\hline Threat Factors & $\begin{array}{c}\text { Maximum Influence } \\
\text { Distance } \mathbf{( k m )}\end{array}$ & Weight & $\begin{array}{c}\text { Decay Linear } \\
\text { Correlation }\end{array}$ \\
\hline $\begin{array}{c}\text { Cultivated land } \\
\text { Urban constructive }\end{array}$ & 4.0 & 0.7 & Exponential \\
land & 5.0 & 1.0 & Exponential \\
Road & 2.0 & 0.5 & Exponential \\
\hline
\end{tabular}

Table 2. Sensitivity of land-use types to the threat factors.

\begin{tabular}{ccccc}
\hline Name & $\begin{array}{c}\text { Habitat } \\
\text { Suitability }\end{array}$ & Cultivated Land & $\begin{array}{c}\text { Urban } \\
\text { Constructive } \\
\text { Land }\end{array}$ & Road \\
\hline Cultivated land & 0.50 & 0.30 & 0.50 & 0.40 \\
Forest & 1.00 & 0.80 & 0.80 & 0.60 \\
Grassland & 0.70 & 0.25 & 0.65 & 0.50 \\
Shrubland & 0.70 & 0.25 & 0.65 & 0.50 \\
water area & 0.80 & 0.65 & 0.60 & 0.50 \\
Construction & 0.00 & 0.00 & 0.00 & 0.00 \\
land & 0.25 & 0.10 & 0.20 & 0.15 \\
Bare land & 0.80 & 0.65 & 0.60 & 0.50 \\
Sea area & & & & \\
\hline
\end{tabular}

The habitat quality index was calculated as follows:

$$
Q_{x j}=H_{j}\left[1-\left(\frac{D_{x j}^{z}}{D_{x j}^{z}+k^{z}}\right)\right]
$$

where $Q_{x j}$ is the habitat quality index of grid $x$ in land use and land cover $j ; D_{x j}$ is the habitat stress level of grid $x$ in land use and land cover $j ; H_{j}$ is the habitat suitability of land use and land cover $j ; k$ is half saturation constant; and $Z$ is a normalized constant, for which the default parameter of the model is 2.5 .

Ecological sources are key natural patches distributed in space that provide important ecosystem functions [17]. Ten regions with superior habitat quality were identified and the relevant habitat patches were extracted based on data from 2020. Patches with an area larger than $7 \mathrm{~km}^{2}$ as the ecological source were extracted. According to the field situation of the study area, most of the habitat patches that were less than $7 \mathrm{~km}^{2}$ were fragmented and should be merged with the nearest ecological source. The ecological source point was taken as the place with the highest habitat quality index.

Urban sources reflect the core driving force of the expansion of construction land in the study area. According to the transitional area with a sharp decline in habitat quality, the urban land was divided into four regions: western, southern, central, and eastern regions. The lowest habitat quality index of each region was taken as the source point of urban expansion [48]. 


\subsection{Establishment of Resistance Surface}

Six factors related to the ecological process and urban expansion were selected as resistance factors: land-use types, the habitat quality index, the normalized difference vegetation index (NDVI), distance from water, distance from residential areas, and distance from roads. The resistance scores were assigned using a five-level system, and a low score indicated low resistance [48]. The original data for each factor were standardized, and the weights were determined by performing principal component analysis. A resistance factor system was constructed to grade the evaluation factors, and the assignment is shown in Table 3.

Table 3. Resistance factor evaluation system.

\begin{tabular}{|c|c|c|c|c|}
\hline $\begin{array}{l}\text { Resistance } \\
\text { Factors }\end{array}$ & Feature & $\begin{array}{c}\text { Ecological } \\
\text { Resistance } \\
\text { Value }\end{array}$ & $\begin{array}{c}\text { Urban } \\
\text { Resistance } \\
\text { Value }\end{array}$ & Weight \\
\hline \multirow{5}{*}{ Land-use types } & $\begin{array}{c}\text { water area, sea area, } \\
\text { forest }\end{array}$ & 1 & 5 & \multirow{5}{*}{0.15} \\
\hline & grassland, shrub land & 2 & 4 & \\
\hline & cultivated land & 3 & 3 & \\
\hline & bare land & 4 & 2 & \\
\hline & construction land & 5 & 1 & \\
\hline \multirow{5}{*}{$\begin{array}{l}\text { Habitat quality } \\
\text { index }\end{array}$} & $>0.80$ & 1 & 5 & \multirow{5}{*}{0.17} \\
\hline & $0.60 \sim 0.80$ & 2 & 4 & \\
\hline & $0.40 \sim 0.60$ & 3 & 3 & \\
\hline & $0.20 \sim 0.40$ & 4 & 2 & \\
\hline & $<0.20$ & 5 & 1 & \\
\hline \multirow{5}{*}{ NDVI } & $0.74 \sim 1$ & 1 & 5 & \multirow{5}{*}{0.17} \\
\hline & $0.44 \sim 0.74$ & 2 & 4 & \\
\hline & $0.17 \sim 0.44$ & 3 & 3 & \\
\hline & $-0.44 \sim 0.17$ & 4 & 2 & \\
\hline & $-1 \sim-0.44$ & 5 & 1 & \\
\hline \multirow{5}{*}{$\begin{array}{l}\text { Distance from } \\
\text { water area }\end{array}$} & $>1000 \mathrm{~m}$ & 1 & 5 & \multirow{5}{*}{0.14} \\
\hline & $750 \mathrm{~m} \sim 1000 \mathrm{~m}$ & 2 & 4 & \\
\hline & $500 \mathrm{~m} \sim 750 \mathrm{~m}$ & 3 & 3 & \\
\hline & $250 \mathrm{~m} \sim 500 \mathrm{~m}$ & 4 & 2 & \\
\hline & $<250 \mathrm{~m}$ & 5 & 1 & \\
\hline \multirow{5}{*}{$\begin{array}{l}\text { Distance from } \\
\text { residential areas }\end{array}$} & $>1100 \mathrm{~m}$ & 1 & 5 & \multirow{5}{*}{0.19} \\
\hline & $800 \mathrm{~m} \sim 1100 \mathrm{~m}$ & 2 & 4 & \\
\hline & $500 \mathrm{~m} \sim 800 \mathrm{~m}$ & 3 & 3 & \\
\hline & $200 \mathrm{~m} \sim 500 \mathrm{~m}$ & 4 & 2 & \\
\hline & $<200 \mathrm{~m}$ & 5 & 1 & \\
\hline \multirow{5}{*}{$\begin{array}{l}\text { Distance from } \\
\text { roads }\end{array}$} & $>1200 \mathrm{~m}$ & 1 & 5 & \multirow{5}{*}{0.18} \\
\hline & $900 \mathrm{~m} \sim 1200 \mathrm{~m}$ & 2 & 4 & \\
\hline & $600 \mathrm{~m} \sim 900 \mathrm{~m}$ & 3 & 3 & \\
\hline & $300 \mathrm{~m} \sim 600 \mathrm{~m}$ & 4 & 2 & \\
\hline & $<300 \mathrm{~m}$ & 5 & 1 & \\
\hline
\end{tabular}

The comprehensive weighted index method was used to construct the resistance surfaces of ecological expansion and urban expansion. The calculation formula is as follows:

$$
Z=\sum_{i=1}^{n} W_{i} \times A_{i}
$$

where $Z$ is the comprehensive resistance value; $W_{i}$ is the weight of resistance factor $i$; $A_{i}$ is the score of resistance factor $i$; and $n$ is the number of resistance factors.

The ecological resistance value is negatively correlated with habitat quality, representing the hindered degree of ecological expansion, as the basis of ecological corridor construction. The urban resistance value is positively correlated with habitat quality, and represents the hindered degree of urban expansion. There is an obvious relationship be- 
tween the two resistance values, and this relationship is an important basis for dividing ecological security zones.

\subsection{Division of Ecological Security Zones}

Ecological security zones define the resistance range of human activities and ecological protection. Based on ecological sources, urban sources, and two types of resistance surfaces, the minimum cumulative resistance values of the ecological and urban sources were calculated using a cost distance tool. Then, the minimum cumulative resistance difference between them was obtained. According to the relationship between the minimum cumulative resistance difference and the number of grids, the resistance threshold method was used to divide the ecological security zones. The principle is that when the ecological flow undergoes sudden changes, the minimum cumulative resistance value will change dramatically, and the value there will be regarded as a potential demarcation point for different ecological security pattern components, to obtain the range of different zones [48]. A minimum cumulative resistance difference value less than 0 was defined as suitable ecological land. It was found that -0.11 was the inflection point where the number of grids changed significantly, so it was used as the threshold value for the division of the ecological preservation zone and limited construction zone. In the same way, a value greater than 0 was defined as suitable urban land, and 0.26 was found as the threshold value for the division of an optimized construction zone and key construction zone.

\subsection{Extraction of Ecological Corridors}

Ecological corridors are the low cumulative resistance channels among ecological sources, conveying the transfer of ecological flow, ecological processes, and ecological functions in a region [49]. Based on the three factors of source, distance, and landscape interface, the MCR model calculates the minimum cost of overcoming the resistance of all landscape units in the process of source diffusion, and regards the channel with the lowest resistance as the ecological corridor between ecological sources [50]. The calculation formula is as follows:

$$
M C R=f_{\min }\left(\sum_{j=n}^{i=m} D_{i j} \times R_{i}\right)
$$

where MCR is the minimum cumulative resistance value; $f$ is an unknown positive function that represents the positive correlation between the minimum resistance at any point in the space and its distance to all sources and the characteristics of the landscape base surface; $D_{i j}$ is the spatial distance of the species from the source $j$ to the landscape unit $i$; and $R_{i}$ is the resistance of the landscape unit $i$ to the movement of the species.

Based on the ecological source point and ecological resistance surface, the cost path tool was used to extract the ecological corridors in the study area. The interaction intensity between ecological sources was calculated using the gravity model to evaluate the importance of the ecological corridors [38]. The calculation formula is as follows:

$$
G_{a b}=k \times \frac{N_{a} N_{b}}{D_{a b}^{2}}=\frac{\left[\frac{1}{p_{a}} \times \ln \left(S_{a}\right)\right]\left[\frac{1}{P_{b}} \times \ln \left(S_{b}\right)\right]}{\left[\frac{L_{a b}}{L_{\max }}\right]^{2}}=\frac{L_{\max }^{2} \ln \left(S_{a} S_{b}\right)}{L_{a b}^{2} P_{a} P_{b}}
$$

where $G_{a b}$ is the interaction between patch A and patch B; $N_{a}$ and $N_{b}$ are the weights of the two patches; $D_{a b}$ is the standardized value of the potential corridor resistance between patch A and patch B; $P_{a}$ and $P_{b}$ are the resistance values of patch $A$ and patch $B$, respectively; $S_{a}$ and $S_{b}$ are the areas of patch $\mathrm{A}$ and patch $\mathrm{B}$, respectively; $L_{a b}$ is the cumulative resistance value of the corridor between patch $A$ and patch $B$; and $L_{\max }$ is the maximum resistance of all corridors in the study area.

There are many repetitive and redundant paths in the process of extracting potential corridors, and these can be simplified using the gravity model. The corridors with the 
highest interaction force were retained and the corridors with relatively large cumulative resistance in similar paths were eliminated.

\subsection{Construction of the Ecological Security Pattern}

Ecological strategic nodes include ecological nodes and ecological fracture points, and their restoration and maintenance are of great significance to maintain the sustainable development of regional ecological functions. Here, the convergence of the minimum cumulative cost path was taken as the ecological node, and the intersection of the minimum cumulative cost path and the maximum cumulative cost path was taken as the ecological fracture point. The maximum cumulative cost path took crossing the urban land as the first choice, which was generated by the ecological source point and the urban resistance surface [51].

Stepping stones are ecological lands with low resistance in the broken landscape. They can be regarded as transit stations or small ecological sources for species migration [52]. When selecting an ecological source, patches that were superior in habitat quality, but which did not satisfy the area requirements, were removed. Taking these small patches as the object, the green space, water area, and other habitats around the potential ecological corridor were selected as stepping-stone patches according to habitat quality. They can be used to reduce the threat to biodiversity due to isolated habitat patches, and to reduce the resistance to animal migration. The final ESP was composed of ecological sources, ecological security zones, ecological corridors, ecological strategic nodes, and stepping-stone patches.

Buffer zone analysis was carried out for the constructed corridors [29]. The buffer distances of $30 \mathrm{~m}, 60 \mathrm{~m}, 100 \mathrm{~m}$, and $200 \mathrm{~m}$ were taken, respectively, and we calculated the percentage of each land use type in the ecological corridor buffer zones under each width [53,54]. Within a certain range, the wider the ecological corridor is, although it may slow down the speed of species migration, it is more likely to form a complete habitat and improve the quality of the ecological corridor. A $30 \mathrm{~m}$-wide corridor can meet the migration conditions of birds and guarantee the basic living conditions of invertebrates and small wild animals, but the biodiversity is low. A $60 \mathrm{~m}$-wide corridor can satisfy the survival of small mammals, reptiles, and amphibians, and has a certain biodiversity [55]. The $100 \mathrm{~m}$ corridor has enabled birds and herbaceous plants to form a greater biodiversity, and many tree groups can survive. The $200 \mathrm{~m}$ corridor is the appropriate width to protect the biodiversity of birds and small mammals [56].

\section{Results}

\subsection{Habitat Quality Assessment and Source Identification}

According to the results of the area analysis of land-use types in 2000, 2010, and 2020 (Figure 3 and Table 4), the area of cultivated land and grassland in Shenzhen has decreased by about half over the past 20 years. The area of forest and water has fluctuated and declined, while the area of shrub land has been relatively stable. Built-up areas have increased by nearly $40 \%$, covering $48.98 \%$ of the study area. 


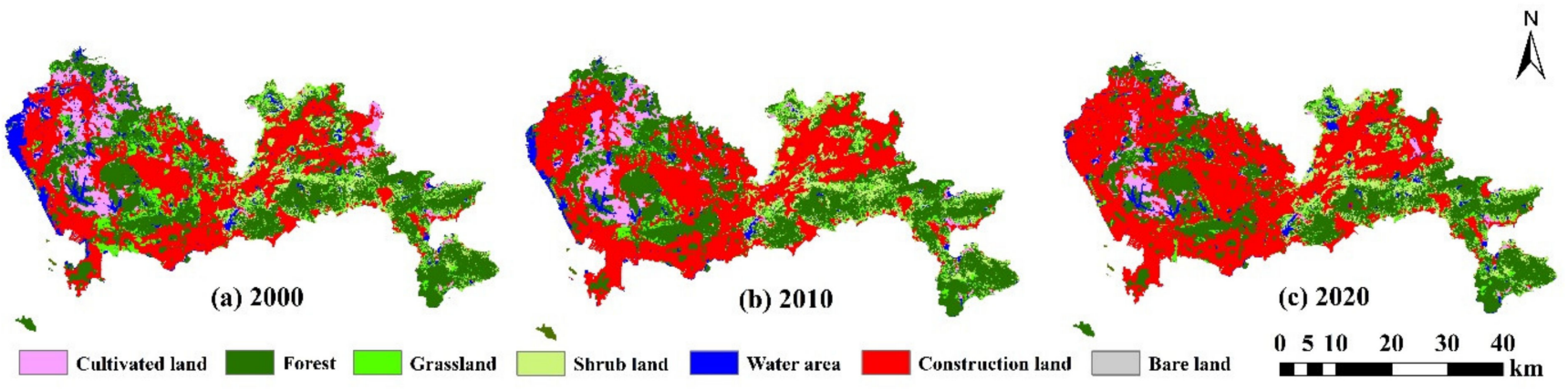

Figure 3. Land-use types of Shenzhen City in (a) 2000, (b) 2010, and (c) 2020.

Table 4. Distribution of land-use types in three periods.

\begin{tabular}{|c|c|c|c|c|c|c|}
\hline \multirow{2}{*}{$\begin{array}{l}\text { Land-Use } \\
\text { Types }\end{array}$} & \multicolumn{2}{|c|}{2000} & \multicolumn{2}{|c|}{2010} & \multicolumn{2}{|c|}{2020} \\
\hline & Area $\left(\mathrm{km}^{2}\right)$ & Proportion (\%) & Area $\left(\mathrm{km}^{2}\right)$ & Proportion (\%) & Area $\left(\mathrm{km}^{2}\right)$ & Proportion (\%) \\
\hline Cultivated land & 149.27 & $7.89 \%$ & 118.01 & $6.24 \%$ & 70.20 & $3.71 \%$ \\
\hline Forest & 660.77 & $34.92 \%$ & 661.39 & $34.97 \%$ & 602.69 & $31.87 \%$ \\
\hline Grassland & 159.18 & $8.41 \%$ & 110.74 & $5.86 \%$ & 89.56 & $4.73 \%$ \\
\hline Shrub land & 147.47 & $7.79 \%$ & 154.46 & $8.17 \%$ & 141.22 & $7.47 \%$ \\
\hline Water area & 109.80 & $5.80 \%$ & 55.69 & $2.94 \%$ & 58.76 & $3.11 \%$ \\
\hline Built area & 662.75 & $35.03 \%$ & 789.04 & $41.72 \%$ & 926.48 & $48.98 \%$ \\
\hline Bare land & 0.05 & $0.00 \%$ & 0.00 & $0.00 \%$ & 0.76 & $0.04 \%$ \\
\hline Sea area & 2.81 & $0.15 \%$ & 2.04 & $0.11 \%$ & 1.72 & $0.09 \%$ \\
\hline
\end{tabular}

The distribution of habitat quality in three periods was obtained using the InVEST model, and the habitat quality was divided into five grades. The specific criteria were as follows: lowest habitat quality (0-0.2), lower habitat quality $(0.2-0.4)$, moderate habitat quality (0.4-0.6), higher habitat quality (0.6-0.8), and highest habitat quality (0.8-1.0).

According to the statistics of each grade area (Table 5), the habitat quality has been declining over the past 20 years. The area with the lowest habitat quality increased gradually, while areas of moderate habitat quality and higher habitat quality decreased. The area with the highest habitat quality changed little from 2000 to 2010, but decreased significantly by 2020 .

Table 5. Classification of habitat quality.

\begin{tabular}{|c|c|c|c|c|c|c|}
\hline \multirow{2}{*}{$\begin{array}{c}\text { Habitat } \\
\text { Quality Grade }\end{array}$} & \multicolumn{2}{|c|}{2000} & \multicolumn{2}{|c|}{2010} & \multicolumn{2}{|c|}{2020} \\
\hline & Area $\left(\mathrm{km}^{2}\right)$ & Proportion (\%) & Area $\left(\mathrm{km}^{2}\right)$ & Proportion (\%) & Area $\left(\mathrm{km}^{2}\right)$ & Proportion (\%) \\
\hline Lowest & 663.58 & $35.07 \%$ & 789.82 & $41.76 \%$ & 927.28 & $49.03 \%$ \\
\hline Lower & 0.05 & $0.00 \%$ & 0.00 & $0.00 \%$ & 0.76 & $0.04 \%$ \\
\hline Moderate & 149.23 & $7.89 \%$ & 117.98 & $6.24 \%$ & 70.16 & $3.71 \%$ \\
\hline Higher & 420.38 & $22.22 \%$ & 323.54 & $17.11 \%$ & 291.80 & $15.43 \%$ \\
\hline Highest & 658.92 & $34.82 \%$ & 660.04 & $34.90 \%$ & 601.40 & $31.80 \%$ \\
\hline
\end{tabular}

In terms of spatial distribution (Figure 4), areas with the highest and higher habitat quality were mainly distributed in large areas of woodland to the southeast, and in the urban green space to the west, while the lowest habitat quality areas were large areas of urban construction land distributed in the central region. The average habitat quality of each district showed a decreasing trend from east to west. The average habitat quality index of the Yantian area and Dapeng New area was the highest. The average habitat quality index of Bao'an District, Guangming District, Nanshan District, Longhua District, Futian District, and Longgang District was relatively low, and that of Luohu District and Pingshan District was general. From 2000 to 2020, construction land in Bao'an District 
increased from $142.93 \mathrm{~km}^{2}$ to $216.3 \mathrm{~km}^{2}$, in Guangming Distrcit it increased from $31.74 \mathrm{~km}^{2}$ to $82.44 \mathrm{~km}^{2}$, and in Longhua District it increased from $82.80 \mathrm{~km}^{2}$ to $116.60 \mathrm{~km}^{2}$. Therefore, the area has witnessed reduced habitat land and the destruction of ecological sources over a relatively short time period.
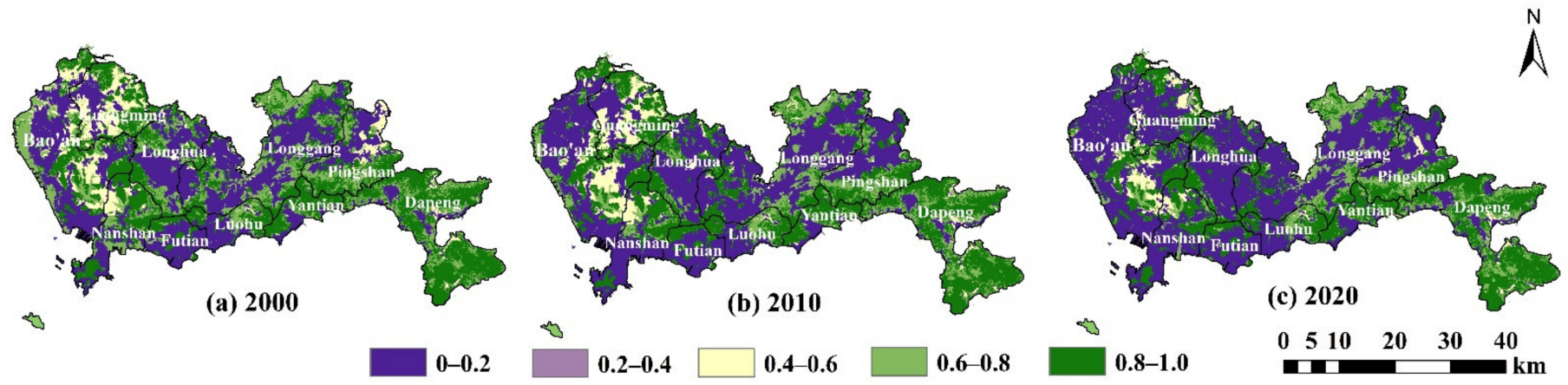

Figure 4. Habitat quality distribution of Shenzhen in (a) 2000, (b) 2010, and (c) 2020.

According to the results of habitat quality, ten optimal habitat patches with large areas were extracted as ecological sources (Figure 5), with an area of $485.81 \mathrm{~km}^{2}$, accounting for $24.32 \%$ of the total study area. They were mainly the rural woodland to the southeast, the urban green land to the west, and forest park patches adjacent to Dongguan and Huizhou in the north. The urban sources of the western, southern, central, and eastern regions were identified, with a total area of $805.865 \mathrm{~km}^{2}$, accounting for $40.34 \%$ of the total study area.

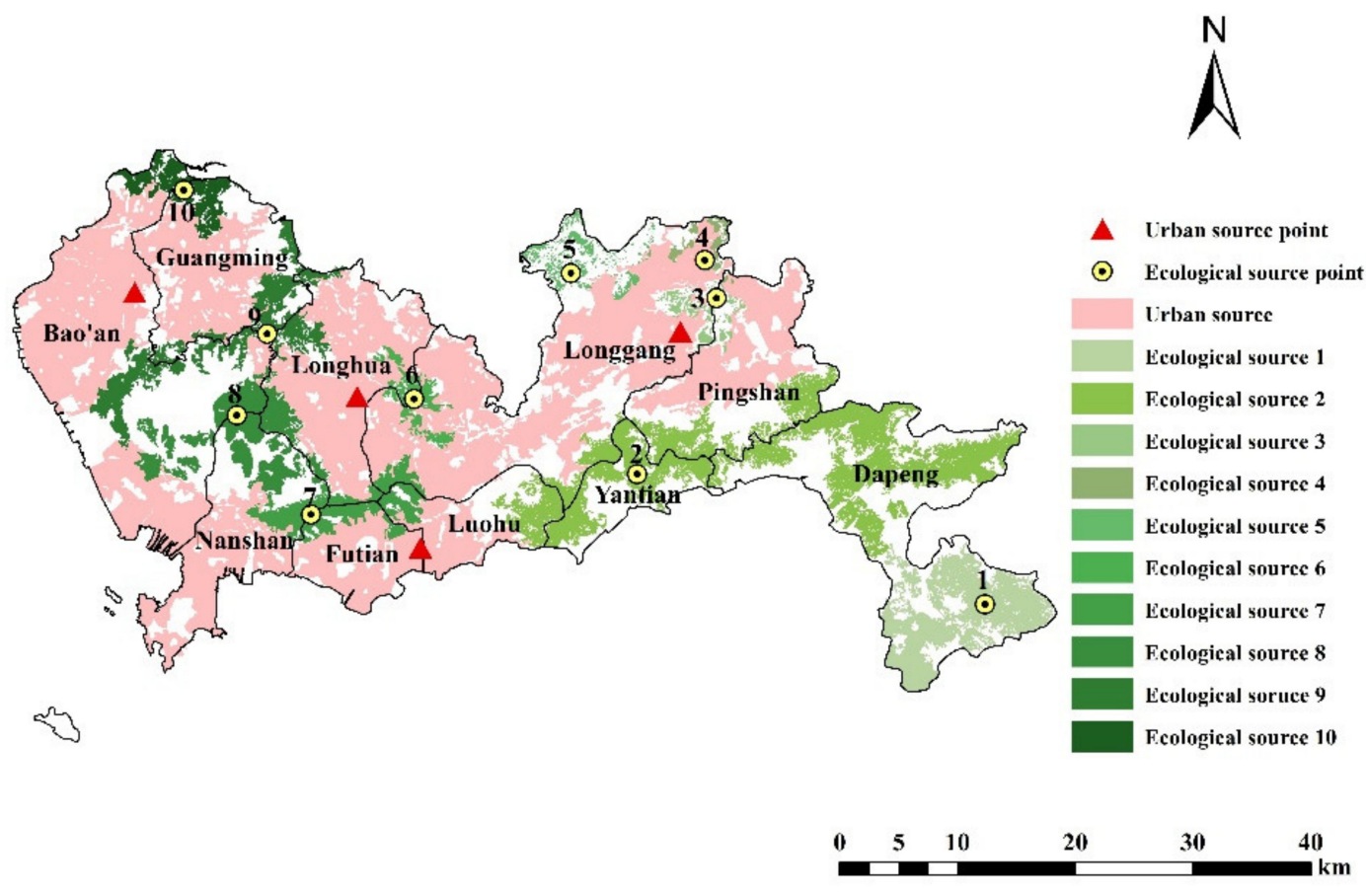

Figure 5. Distribution of ecological sources and urban sources.

\subsection{Division of Ecological Security Zones}

The constructed resistance surface showed that a large area of the urban construction land was highly resistant to ecological expansion, and that the habitat patches were isolated from each other (Figure 6). 


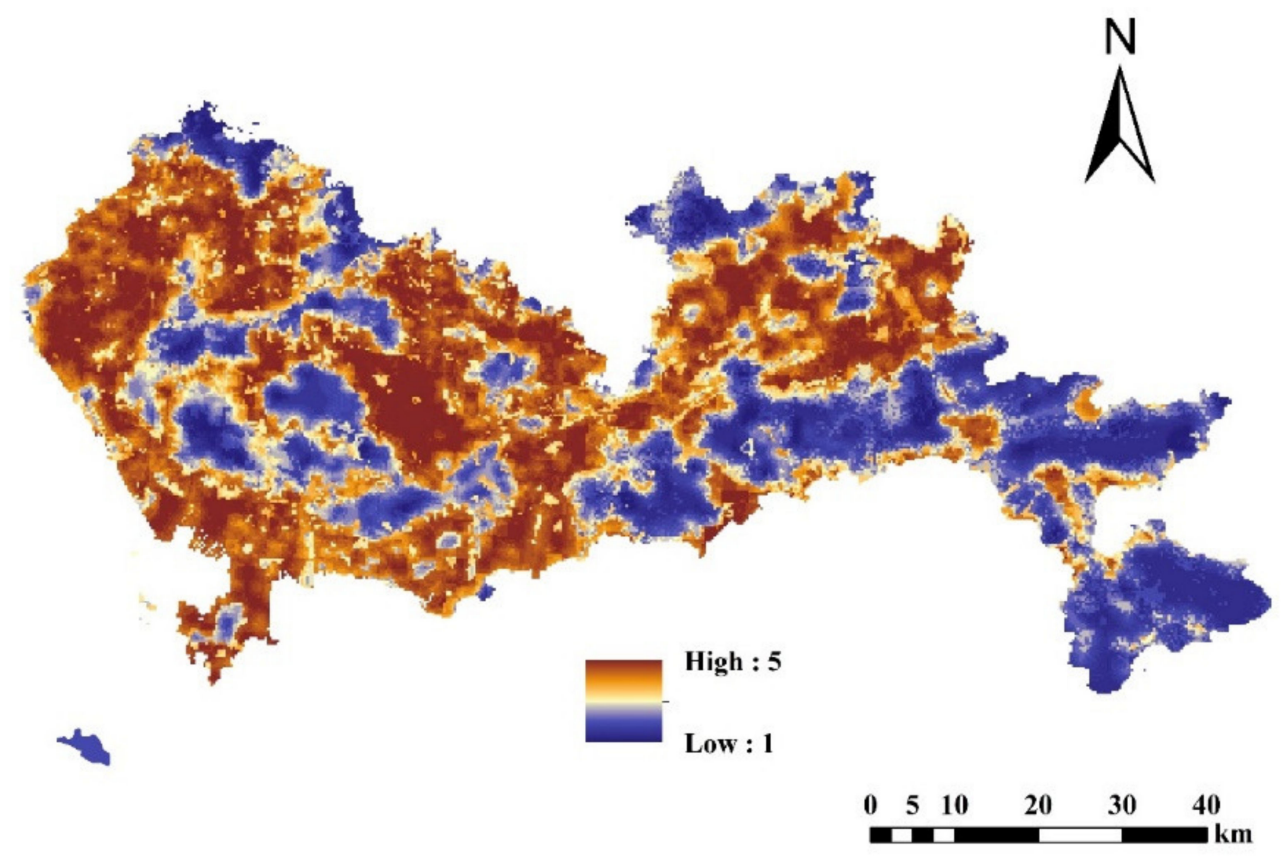

Figure 6. Resistance value distribution in the study area.

According to the results of the minimum cumulative resistance difference between ecological expansion and urban expansion, preliminary zoning was carried out (Figure 7). The positive value area was suitable for urban land use and the negative value area was suitable for ecological land use. Among them, the area of suitable urban land was $1338.906 \mathrm{~km}^{2}$, accounting for $67.03 \%$ of the study area. The area of suitable ecological land was $658.564 \mathrm{~km}^{2}$, accounting for $32.97 \%$ of the study area.
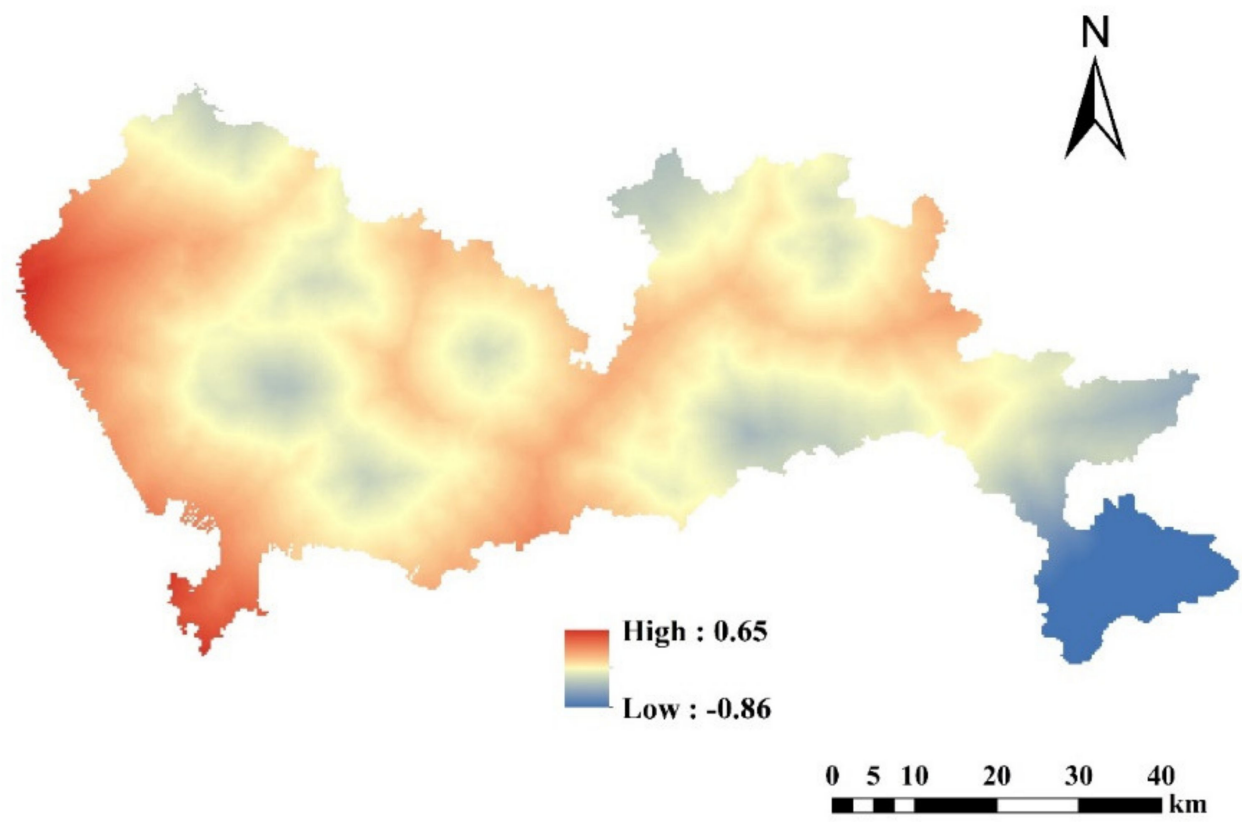

Figure 7. Distribution of the minimum cumulative resistance difference.

Using the resistance threshold method, suitable urban land was further divided into a key construction zone and an optimized construction zone. Suitable ecological land was divided into an ecological preservation zone and a limited construction zone (Figure 8). It should be noted that the cumulative resistance value could only be calculated from the 
source point to the continental margin of the study area, so the islands in the study area need to be supplemented for zoning.
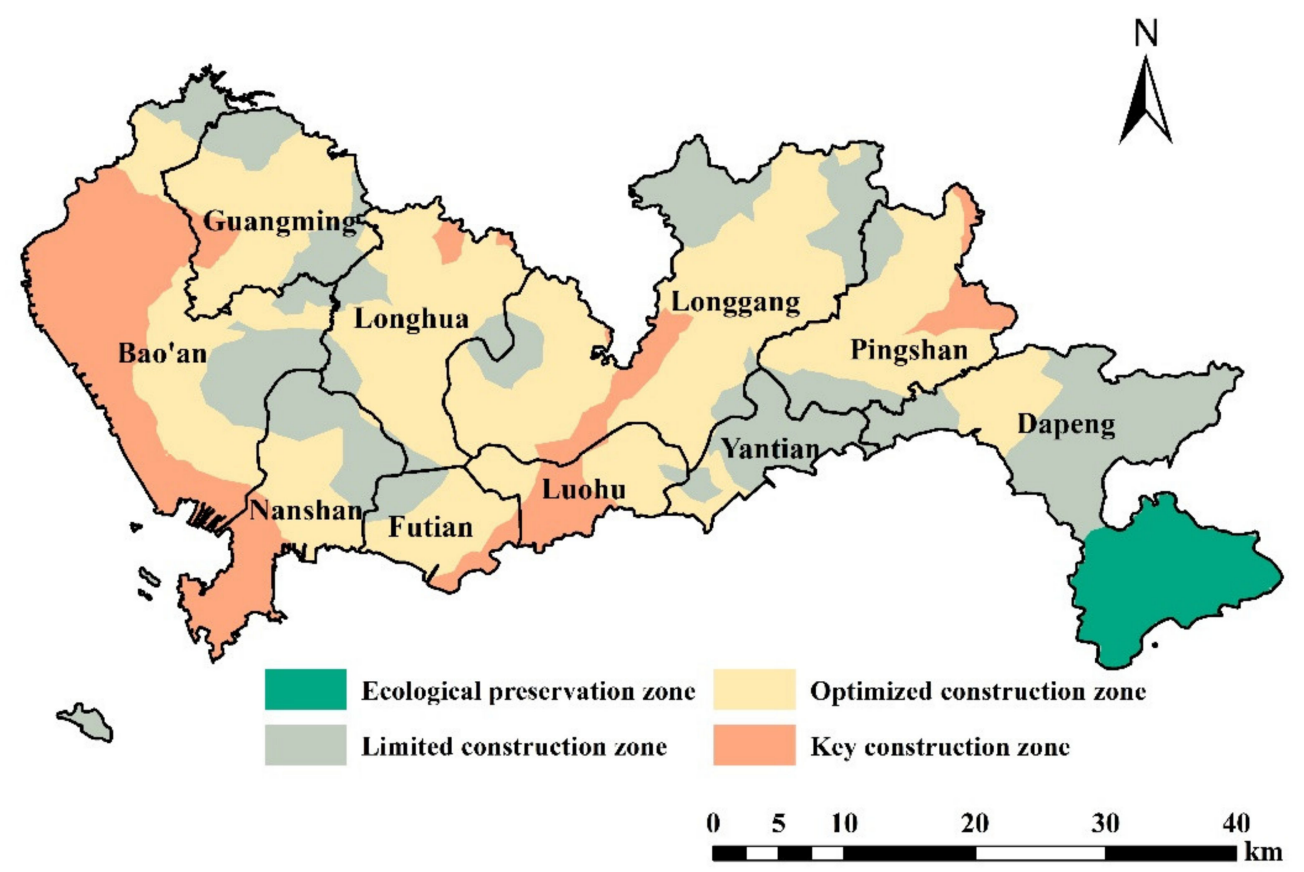

Figure 8. Ecological security zones in the study area.

According to the statistical results of the area of each district (Table 6), the largest was the optimized construction zone, with an area of $997.736 \mathrm{~km}^{2}$, accounting for $49.95 \%$ of the total area. This area was mainly concentrated in the western and central regions, coinciding with the urban construction area of Shenzhen. The second largest was the limited construction zone, with an area of $544.331 \mathrm{~km}^{2}$, accounting for $27.25 \%$ of the total area. This area was mainly distributed in ecological areas such as forests, grassland, shrub land, and water areas, except the woodland of the Dapeng Peninsula. The area of the key construction zone was $341.170 \mathrm{~km}^{2}$, accounting for $17.08 \%$ of the area. This area was mainly distributed to the west of Bao'an District, the southwest of Nanshan District, and the middle of Luohu District. The smallest area was the ecological preservation zone, with an area of $114.233 \mathrm{~km}^{2}$, accounting for $5.72 \%$ of the total area. This area was distributed to the southeast of Dapeng District.

According to the area and proportion of each land-use type (Table 7), the land in the ecological preservation zone were mainly forest, shrub, and grassland. In the limited construction zone, the largest area was forest, accounting for $63.27 \%$ of the total area, and the second was the built area, accounting for $23.30 \%$. The optimized construction zone mainly comprised built-up areas, accounting for $69.41 \%$ of the area, followed by forests, accounting for $20.57 \%$. In the key construction zone, built-up areas accounted for $86.96 \%$, followed by a small amount of forest. 
Table 6. Ecological security zoning.

\begin{tabular}{|c|c|c|c|c|c|}
\hline $\begin{array}{l}\text { Appropriate } \\
\text { Partition Type }\end{array}$ & $\begin{array}{c}\text { Area } \\
\left(\mathrm{km}^{2}\right)\end{array}$ & $\begin{array}{c}\text { Ecological } \\
\text { Security Zones }\end{array}$ & $\begin{array}{l}\text { Grading } \\
\text { Range }\end{array}$ & $\begin{array}{c}\text { Area } \\
\left(\mathrm{km}^{2}\right)\end{array}$ & Proportion \\
\hline Suitable ecological & 658.56 & $\begin{array}{c}\text { Ecological } \\
\text { preservation zone }\end{array}$ & $-0.86-0.11$ & 114.23 & $5.72 \%$ \\
\hline \multirow{3}{*}{$\begin{array}{l}\text { Suitable urban } \\
\text { land }\end{array}$} & \multirow{3}{*}{1338.91} & $\begin{array}{l}\text { Limited } \\
\text { construction zone }\end{array}$ & $-0.11-0.00$ & 544.33 & $27.25 \%$ \\
\hline & & $\begin{array}{c}\text { Optimized } \\
\text { construction zone }\end{array}$ & $0.00-0.26$ & 997.74 & $49.95 \%$ \\
\hline & & $\begin{array}{l}\text { Key construction } \\
\text { zone }\end{array}$ & $0.26-0.65$ & 341.17 & $17.08 \%$ \\
\hline
\end{tabular}

Table 7. Land-use types in ecological security zones.

\begin{tabular}{|c|c|c|c|c|c|c|c|c|}
\hline \multirow{2}{*}{$\begin{array}{c}\text { Land-Use } \\
\text { Types }\end{array}$} & \multicolumn{2}{|c|}{$\begin{array}{c}\text { Ecological Preservation } \\
\text { Zone }\end{array}$} & \multicolumn{2}{|c|}{$\begin{array}{c}\text { Limited Construction } \\
\text { Zone }\end{array}$} & \multicolumn{2}{|c|}{$\begin{array}{c}\text { Optimized Construction } \\
\text { Zone }\end{array}$} & \multicolumn{2}{|c|}{ Key Construction Zone } \\
\hline & Area $\left(\mathrm{km}^{2}\right)$ & Proportion & Area $\left(\mathrm{km}^{2}\right)$ & Proportion & Area $\left(\mathrm{km}^{2}\right)$ & Proportion & Area $\left(\mathrm{km}^{2}\right)$ & Proportion \\
\hline $\begin{array}{l}\text { Cultivated } \\
\text { land }\end{array}$ & 1.87 & $1.64 \%$ & 27.47 & $5.05 \%$ & 35.17 & $3.53 \%$ & 4.63 & $1.36 \%$ \\
\hline Grassland & 2.99 & $2.61 \%$ & 8.27 & $1.52 \%$ & 8.72 & $0.87 \%$ & 1.29 & $0.38 \%$ \\
\hline Forest & 100.95 & $88.37 \%$ & 346.86 & $63.72 \%$ & 205.28 & $20.57 \%$ & 28.23 & $8.27 \%$ \\
\hline Built area & 1.78 & $1.56 \%$ & 126.81 & $23.30 \%$ & 692.57 & $69.41 \%$ & 296.70 & $86.96 \%$ \\
\hline Water area & 1.65 & $1.44 \%$ & 15.11 & $2.78 \%$ & 22.35 & $2.24 \%$ & 4.90 & $1.43 \%$ \\
\hline Shurb land & 4.72 & $4.14 \%$ & 19.69 & $3.62 \%$ & 33.63 & $3.37 \%$ & 5.43 & $1.59 \%$ \\
\hline Bare land & 0.27 & $0.23 \%$ & 0.13 & $0.02 \%$ & 0.00 & $0.00 \%$ & 0.00 & $0.00 \%$ \\
\hline Total & 114.23 & $100.00 \%$ & 544.33 & $100.00 \%$ & 997.74 & $100.00 \%$ & 341.17 & $100.00 \%$ \\
\hline
\end{tabular}

\subsection{Construction of Ecological Corridors}

A total of 45 ecological corridors were constructed using the MCR model, with a total length of $748.85 \mathrm{~km}$. The interaction intensity between the ecological sources was quantified using the gravity model. According to the statistical results of the ecological source interaction intensity (Table 8), redundant corridors were removed and the ecological corridors were divided into three grades. The specific criteria were as follows: those with a value greater than 3 were regarded as Level 1 corridors, those at 1-3 were Level 2 corridors, and those with a value less than 1 were Level 3 corridors (Figure 9). Among them, there were eight Level 1 corridors with a total length of $105.39 \mathrm{~km}$, five Level 2 corridors with a total length of $106.03 \mathrm{~km}$, and six Level 3 corridors with a total length of $221.77 \mathrm{~km}$.

Table 8. Interaction intensity of the ecological sources.

\begin{tabular}{|c|c|c|c|c|c|c|c|c|c|c|}
\hline $\begin{array}{c}\text { Ecological } \\
\text { Source Number }\end{array}$ & 1 & 2 & 3 & 4 & 5 & 6 & 7 & 8 & 9 & 10 \\
\hline 1 & 0.00 & 2.16 & 0.74 & 0.64 & 0.56 & 0.36 & 0.40 & 0.34 & 0.27 & 0.21 \\
\hline 2 & & 0.00 & 2.91 & 2.20 & 3.09 & 1.83 & 1.74 & 1.17 & 0.82 & 0.52 \\
\hline 3 & & & 0.00 & 28.13 & 3.21 & 0.30 & 0.33 & 0.27 & 0.21 & 0.15 \\
\hline 4 & & & & 0.00 & 4.22 & 0.30 & 0.30 & 0.25 & 0.21 & 0.15 \\
\hline 5 & & & & & 0.00 & 0.77 & 0.56 & 0.44 & 0.43 & 0.28 \\
\hline 6 & & & & & & 0.00 & 2.95 & 1.65 & 2.34 & 0.83 \\
\hline 7 & & & & & & & 0.00 & 9.88 & 3.29 & 1.00 \\
\hline 8 & & & & & & & & 0.00 & 13.86 & 2.10 \\
\hline 9 & & & & & & & & & 0.00 & 4.62 \\
\hline 10 & & & & & & & & & & 0.00 \\
\hline
\end{tabular}




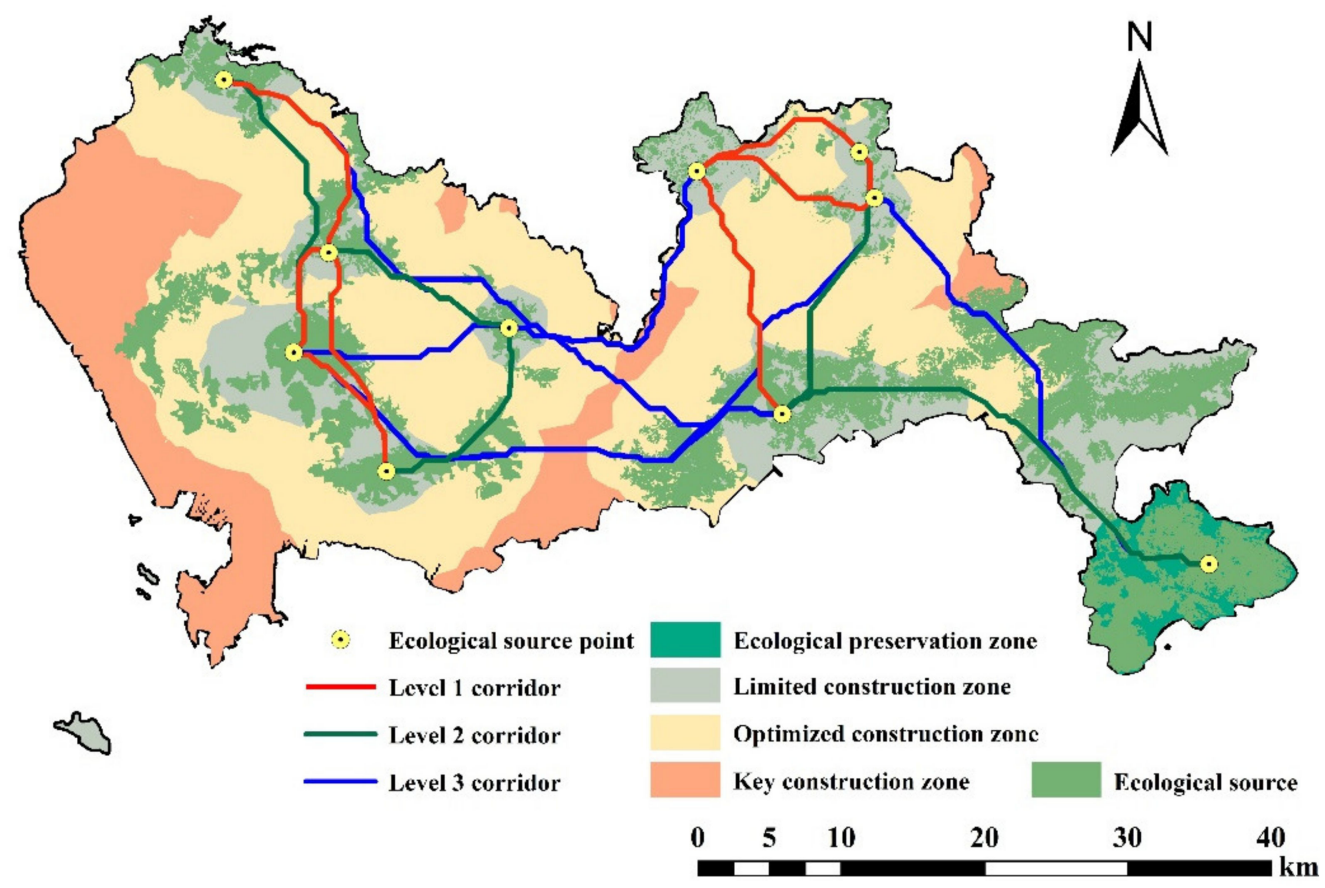

Figure 9. Distribution of ecological corridors in Shenzhen City.

Level 1 corridors were irreplaceable and connected the ecological sources with the greatest intensity of interaction. Level 2 corridors played the role of auxiliary Level 1 corridors, forming ecological flow from east to west. Level 3 corridors formed an ecological network across the study area, which played a role in connecting the ecological flow from east to west.

\subsection{Construction of the Ecological Security Pattern}

A total of 26 ecological nodes were identified. These nodes were the convergence points of the minimum cumulative cost paths. The low-level corridors merged into highlevel corridors through these nodes, which played an important role in maintaining the operation of the ecological flow. Ecological fracture points to some extent represented barriers and the destruction of a corridor after leaving the source. We identified 16 sites with fragile links in the ecological corridors. Stepping stones as small habitats can provide support for the existing corridors and can be used as a biological respite, and 16 such sites were identified.

The ESP of Shenzhen was obtained by integrating ecological sources, ecological source points, ecological security zones, ecological corridors, ecological strategic nodes, and stepping stones (Figure 10). 


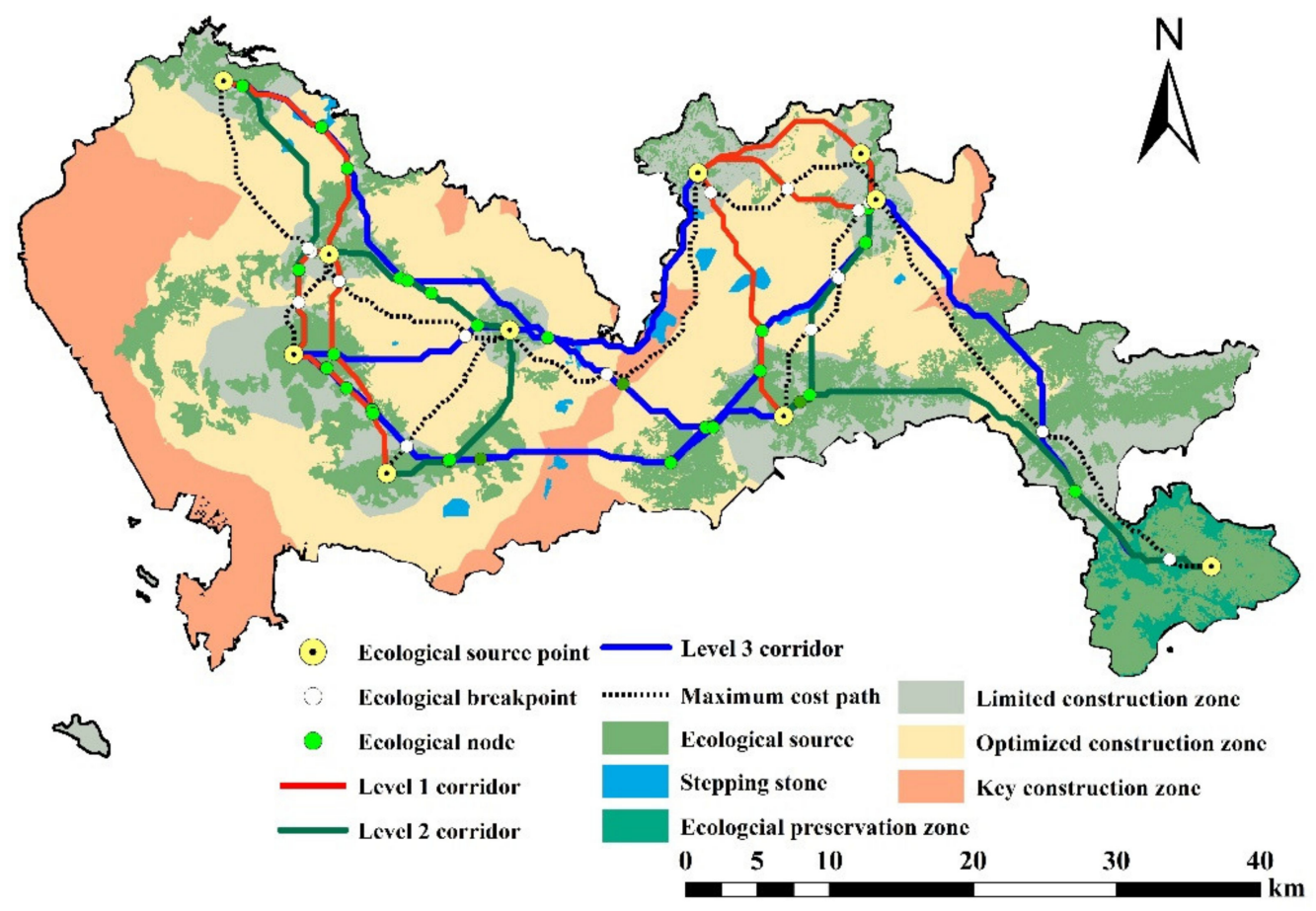

Figure 10. Ecological security pattern in Shenzhen City.

The results of land-use type analysis of corridors with different widths (Table 9) showed the woodland area significantly decreased with the increasing imaginary widths of corridors, while that of construction was the opposite. For example, the percentage of forest inclined from $59.02 \%$ in $30 \mathrm{~m}$ to $54.94 \%$ in $200 \mathrm{~m}$.

Table 9. Land-use type analysis of corridors with different widths.

\begin{tabular}{|c|c|c|c|c|c|c|c|c|}
\hline \multirow{2}{*}{$\begin{array}{l}\text { Land-Use } \\
\text { Types }\end{array}$} & \multicolumn{2}{|c|}{$30 \mathrm{~m}$} & \multicolumn{2}{|c|}{$60 \mathrm{~m}$} & \multicolumn{2}{|c|}{$100 \mathrm{~m}$} & \multicolumn{2}{|c|}{$200 \mathrm{~m}$} \\
\hline & $\begin{array}{l}\text { Area } \\
\left(\mathrm{km}^{2}\right)\end{array}$ & $\begin{array}{c}\text { Percentage } \\
(\%)\end{array}$ & $\begin{array}{l}\text { Area } \\
\left(\mathbf{k m}^{2}\right)\end{array}$ & $\begin{array}{c}\text { Percentage } \\
(\%)\end{array}$ & $\begin{array}{c}\text { Area } \\
\left(\mathbf{k m}^{2}\right)\end{array}$ & $\begin{array}{c}\text { Percentage } \\
(\%)\end{array}$ & $\begin{array}{c}\text { Area } \\
\left(\mathrm{km}^{2}\right)\end{array}$ & $\begin{array}{c}\text { Percentage } \\
(\%)\end{array}$ \\
\hline $\begin{array}{c}\text { Cultivated } \\
\text { land }\end{array}$ & 0.60 & $2.74 \%$ & 1.11 & $2.64 \%$ & 1.82 & $2.65 \%$ & 3.74 & $2.85 \%$ \\
\hline Forest & 12.81 & $59.02 \%$ & 24.83 & $58.77 \%$ & 39.71 & $57.72 \%$ & 72.13 & $54.94 \%$ \\
\hline Grassland & 1.12 & $5.15 \%$ & 2.20 & $5.22 \%$ & 3.69 & $5.37 \%$ & 7.43 & $5.66 \%$ \\
\hline Shurb land & 2.62 & $12.06 \%$ & 5.11 & $12.09 \%$ & 8.44 & $12.28 \%$ & 16.24 & $12.37 \%$ \\
\hline Water area & 0.93 & $4.30 \%$ & 1.76 & $4.17 \%$ & 2.81 & $4.08 \%$ & 5.31 & $4.05 \%$ \\
\hline Built area & 3.63 & $16.73 \%$ & 7.23 & $17.11 \%$ & 12.31 & $17.90 \%$ & 26.43 & $20.13 \%$ \\
\hline
\end{tabular}

\section{Discussion}

\subsection{Habitat Quality Assessment}

Our results showed that construction land in the central parts of Shenzhen has gradually increased in area, showing a pattern of continuous expansion while occupying ecological space (Table 4), and low habitat quality dominated by urban construction land had been encroaching on the surrounding area over the past 20 years (Table 5 and Figure 4). Rural woodlands and urban forest parks shape the whole spatial pattern of habitats. The mountains of Shenzhen are mainly distributed to the southeast, and relatively complete high-quality habitat is preserved in these mountainous areas. Most of the other areas are densely populated areas with high human socio-economic activities and low habitat quality. The distribution pattern of habitat quality in Shenzhen is high in the east and low in the west, whereas it is high in the north and low in the central and southern 
locations. The spatial response of the natural environment to socio-economic activities highlights the dynamic change of the habitat quality distribution pattern [57]. Specially, in areas with rapid economic development, a high population density, and enhanced urban vitality, biodiversity is reduced, and the integrity of the ecosystem is destroyed [57]. A large area of moderate and high-quality habitat patches has been replaced in Bao'an District, Guangming District, and Longhua District, reflecting the phenomenon of urban expansion.

However, the southeast of Shenzhen has maintained a large area of high-quality habitat over the past 20 years, and there is no obvious reduction compared with the basic ecological control line. According to the Green Pearl River Delta road network master plan outline [58], this area is consistent with the green buffer belt of the Wutong MountainMaluan Mountain-Nan'ao-Xichong-Qiniang Mountain, which can protect the construction of the Pearl River Delta No. 2 Greenway (Shenzhen section). Therefore, to maintain highquality habitat patches, more attention should be paid to areas with a high risk of ecological degradation. Broken ecological patches can be distributed to large nearby habitats through ecological corridors, and, in combination with artificial restoration, the trend of urban ecological degradation can be effectively suppressed.

\subsection{Construction of the Ecological Security Pattern}

ESPs have been a hot research topic in recent years, offering a spatial planning method that can balance urban development and ecological protection [59]. When making regional development plans, it is particularly important for decision-makers to specify the key ecological patches that need to be protected and areas suitable for development and construction. This is done to mediate the contradiction between regional ecological security and economic development [59]. We identified the important components of ESPs and constructed a regional ESP for Shenzhen City, and an optimized pattern with one axis, three belts, and four zones was thus developed. This pattern can be used to improve the spatial connectivity of the whole landscape ecosystem and enhance the resilience of urban restoration [32].

In this study, the results of the InVEST model regarding habitat quality were used to extract ecological sources. The main threat to urban ecological land conservation is construction land, and secondary threats include cultivated land and roads. The method simulates the sensitivity of different land-use types to threat factors and evaluates the habitat quality of each unit. This is used to characterize the optimal survival, reproduction, and energy flow conditions for organisms in the assessment unit [27]. In addition to contributing to the study of how human activities affect habitat quality and animal migration, this information is expected to help assess landscape resistance in different units. Superior habitat quality promotes ecological flow and corresponds to low resistance. Our habitat quality assessments based on habitat suitability and threat sources were representative to some extent, and our results were consistent with the ecological sources selected by Peng et al. [44], based on the functional importance of ecological land and the risk of the functional degradation of ecological land.

An ecological resistance surface is an ecological process that simulates the spatial movement of species. Ecological resistance is an obstacle to ecological flow and transmission among different landscape types [60]. We used a comprehensive weighted index sum to determine the coefficient of resistance by comprehensively considering the influence of land-use types, habitat quality, the NDVI, road networks, water areas, and residential area, so as to combine the environmental characteristics of Shenzhen City, which is a novel method for coupling ecological resistance and urban resistance. A low resistance area is an area where the habitat is well preserved. Except for a large area in the southeast of the study area, low resistance areas were distributed sporadically in the north and west of the study area, which indicated that the high resistance area blocked the communication between different habitats, resulting in landscape fragmentation.

Ecological security zoning is based on the theory of landscape ecology. It proceeds from the present situation of regional land use, considering the natural, social, and eco- 
nomic conditions of the region, and involves clustering the land according to the suitability of the relevant use functions in an appropriate way [61]. Current data on regional land-use types are the basis for suitability zoning. For the expansion of construction land, the expansion process is restricted by the functions of ecosystem, while for the expansion of ecological land, expansion is driven by the functions of the ecosystem. Therefore, the same patch has the opposite effect on the expansion of urban land and ecological land. In this study, the MCR model was used to achieve this role. Combining the general principles of suitability zoning with the actual situation, the study area was divided into four areas: an ecological preservation zone, a limited construction zone, an optimized construction zone, and a key construction zone.

As a key ecological component in the ESP, ecological corridors were identified with the MCR model, because the data requirements are relatively simple [62], and because the results can be expressed visually. The MCR model can simulate the spatial movement process affected by landscape units to a certain extent, and has advantages in expressing the interaction between various ecological processes and security patterns. In this study, the collection of low resistance values constituted the ecological nodes in the regional ecological security pattern. Ecological nodes were set up according to the distribution of ecological corridors. These nodes play an important role in maintaining the versatility and structural integrity of the regional ecosystem. We constructed not only the ecological resistance surface but also the resistance surface of urban expansion. The resistance surface of urban expansion can be used to construct the maximum cost path between the source areas. Thus, we could identify ecological fracture points, which were generally the places where the ecological corridor was blocked by a high-grade highway, indicating the need for the restoration and maintenance of the corridors.

Using the InVEST model and the MCR model, we obtained a multi-level spatial scheme consisting of points, lines, planes, and networks. This scheme is conducive to the implementation of protective measures and the optimization of objectives, such as ecological security zones, ecological corridors, ecological strategic nodes, and stepping stones. It therefore served as the basis for constructing the ESP for Shenzhen City, and it can be used as a reference for the construction of ESPs for other similar cities. However, we focused on habitat quality and neglected other indicators of diversity, such as ecological sensitivity and ecological functions, which are also important for the conservation of biodiversity. At the same time, as a typical case of highly urbanized development, Shenzhen has complex and diverse socio-economic factors. If conditions permit, more regional industrial and population development data should be combined to further study the coupling scheme between socio-economic development and regional ecological security.

The results of the corridor-width analysis (Table 9) suggest that their appropriately designed widths are between 30 and $60 \mathrm{~m}$ in Shenzhen City. These widths have been demonstrated by previous studies to provide greater biodiversity and enable the survival of small mammals and birds [63]. For example, Yang et al. (2018) pointed out that the appropriate width of the planning ecological corridor was 30-60 m in Guangzhou City, a similar city about $138 \mathrm{~km}$ from our study city [54]. When the width of the corridor reaches $200 \mathrm{~m}$, the construction land accounts for more than $20 \%$, and the buffer area of the corridor will be disturbed by more human factors, which is not suitable for ecological corridor planning.

\subsection{Implications for the Development of an Ecological City in Shenzhen City}

Compared with the ecological zones for the Ecological City Construction Plan of Shenzhen in 2007 (Figure 11) [64], the scope of the ecological preservation zone and limited construction zone in this paper was reduced compared with the key protected zone, but still included important habitats such as nature reserves, water conservation areas, scenic spots, forests, and country parks. In particular, our results from east to west in the study area cover the Qiniang Mountain Biodiversity Reserve, the Paiya Mountain-Bijia MountainTianxin Mountain Biodiversity Reserve, the Ma Luanshan Important Mountain Protection 
Zone, the Sanzhoutian Reservoir Biodiversity Reserve, the Qinglinjing Reservoir water conservation area, the Tanglang Mountain Forest Park, the Yangtai Mountain Forest Park, and the Luotian Reservoir water conservation area. In general, the ecological sources extracted in this study are mainly rural woodlands to the southeast, urban green land to the west, and forest park patches adjacent to Dongguan and Huizhou in the north. In addition to the clear boundary of ecological sources, we should also pay attention to connecting the habitat and the ecological land between cities, so as to realize shared ecological land, and to respond to the call for a Green Living Circle in the Greater Pearl River Delta [65].

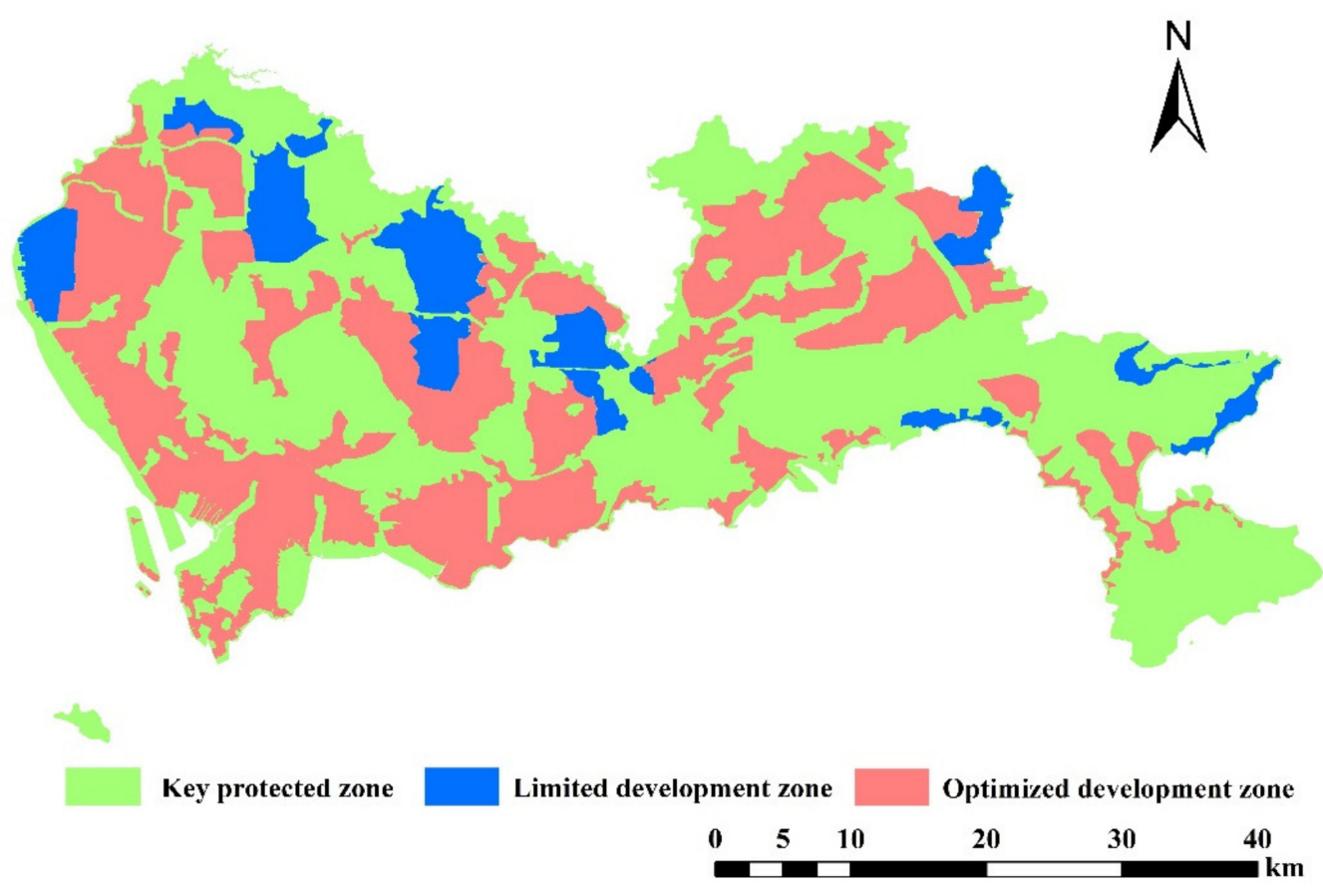

Figure 11. Ecological function zoning in the "Ecological City Construction Plan of Shenzhen" (revised from the General Office of the People's Government of Shenzhen Municipality (2007)).

The optimized construction zone identified in this paper overlapped with the comprehensive construction area of urban settlements, the eastern industrial development and construction area, and the central comprehensive development and construction area mentioned in the Ecological City Construction Plan of Shenzhen [64]. The key construction zones were mainly the western coastal ecological industry development and construction zones [64]. In this regard, we should pay attention to greenbelt compensation in the process of construction, and we should take into account the ecological and economic benefits of the land.

Over the past 20 years, major habitat patches have been preserved, and changes were mainly to patches at the edges of the habitat. However, these patches can be used as small habitats and are conducive to biological dispersal between habitat patches in areas of intensive human activity [66]. In particular, we identified a number of stepping-stone patches as greenbelt compensation for the process of construction, including Shiyaling Sports Park, Honghu Park, Lianhuashan Park, Dayun Park, Longcheng Park, Yanziling Park, and urban green belts along major traffic lines.

Our study identified ecological corridors in a spatial pattern with one axis and three belts (Figure 10). Specifically, one axis referred to an ecological corridor from east to west, which maintained the ecological connectivity from Yangtai Mountain to Qiniang Mountain. The three belts referred to three south-north ecological corridors. The western corridor reached from Luotian Forest Park to Tanglang Mountain, the central corridor started at Qinglinjing Forest Park and ran to Maluan Mountain, and the east corridor extended from Pingdi Forest Park to Qiniang Mountain. An ecological network formed around the 
ecological sources to ensure the continuation of ecological processes from east to west and south to north.

In view of the ecological corridor plan mentioned in the Master Plan for the National Forest City Construction of Shenzhen (2016-2025) [67], our results can serve as a reference for its restoration and construction. The specific areas include the northern border between Shenzhen and Dongguan; the coastal zone of the Yantian and Dapeng districts; the area comprising Guangming, Guanlan, and Longhua; the Qinglinjing-Pingdi green space; the Songzikeng green space; and the Sanzhoutian-Maluan Mountain area. Compared with the Pearl River Delta Greenway Network (Shenzhen Section) in the Green Pearl River Delta Road Network Master Plan Outline [48], this study supplemented an ecological corridor connecting the eastern Qinglinjing Forest Park, Songzikeng Reservoir, and Maluan Mountain Country Forest. However, some habitats to the west were identified as a whole and the source points were extracted in the east, which led to the lack of ecological corridors in the area of Luotian Forest Park and Fenghuang Mountain. Therefore, the source points should be increased in the west to solve this problem.

The ecological corridors identified in this paper generally conformed to the system of four belts and six corridors in Shenzhen [64], and they were consistent with the ecological corridor of Longgang River-Pingshan River-Dapeng Peninsula in the east. In the central and western regions, the corridors can connect to the Pinghu-Buji-Shenzhen River ecological corridor, the Yangtai Mountain-Wutong Mountain-Pingshan River ecological corridor, and a traffic corridor along the G15 national highway, thus increasing the connections between regional ecological sources and improving the connectivity of the eastern and western ecological corridors.

The central government of China released the National New-type Urbanization Plan in 2014, with the target of increasing China's urban population by $1 \%$ each year, to reach $60 \%$ by 2020 [9]. The increase in population in megacities corresponds to a high demand for construction land. In fact, construction land is developing more quickly as the urban population is increasing in China [44]. Therefore, in order to prevent the transformation of ecological land into construction land, it is essential to define a suitable development limit between them. Our results provide a scientific reference for this. In the future, ecological sources should be protected and landscape connectivity should be increased by adopting measures for constructing and restoring ecological corridors. At the same time, attention should be paid to the protection of ecological strategic nodes and their connection with stepping-stone patches. In short, the construction of ESPs is urgently needed in the current urbanization process of China.

\section{Conclusions}

Based on habitat quality assessment and the MCR model, an ecological security pattern was identified and optimized for Shenzhen City, a rapidly urbanizing city in China. The results showed that the average habitat quality in Shenzhen has decreased over the past 20 years. Ten ecological sources were identified with superior habitat quality, which were mainly located in the southeast, west, and north sections of the city. An optimized pattern for Shenzhen City with one axis, three belts, and four zones was proposed. Among them, four zones-an ecological preservation zone, a limited development zone, an optimized development zone, and a key development zone-were generated. Moreover, forty-five ecological corridors were extracted and graded into three levels, presenting a spatial pattern of one axis and three belts. The appropriate widths of the ecological corridors were suggested to be 30-60 $\mathrm{m}$ in Shenzhen City. In addition, twenty-five ecological nodes, sixteen ecological fracture points, and sixteen stepping stones were identified to improve the maintenance and construction of the ecological corridor network. The findings of this study can serve as a scientific reference for urban ecological protection. 
Author Contributions: Conceptualization, Z.-Y.J. and Y.-Z.Z.; methodology, Z.-Y.J., Y.-Z.Z. and Y.Y.L.; software, Y.-Z.Z. and Y.-Y.L.; validation, Z.-Y.J. and Z.-G.Y.; data curation, X.-H.W. and X.-B.L.; writing-original draft preparation, Y.-Z.Z. and Z.-Y.J.; writing-review and editing, Z.-Y.J. and Z.-G.Y.; visualization, X.-H.W. and X.-B.L.; supervision, Z.-Y.J.; project administration, Z.-Y.J.; funding acquisition, Z.-Y.J. All authors have read and agreed to the published version of the manuscript.

Funding: This research was funded by National Natural Science Foundation of China (Grant No. 41901027), Natural Science Foundation of Guangdong Province, China (2021A1515012208) and China Postdoctoral Science Foundation (2021T140222).

Institutional Review Board Statement: Not applicable.

Informed Consent Statement: Not applicable.

Data Availability Statement: The data presented in this study are available on request from the corresponding author.

Conflicts of Interest: The authors declare no conflict of interest.

\section{References}

1. Pfeifer, M.; Lefebvre, V.; Peres, C.A.; Banks-Leite, C.; Wearn, O.; Marsh, C.; Butchart, S.H.M.; Arroyo-Rodríguez, V.; Barlow, J.; Cerezo, A.; et al. Creation of forest edges has a global impact on forest vertebrates. Nat. Cell Biol. 2017, 551, 187-191. [CrossRef] [PubMed]

2. Yu, Q.; Hu, Q.; van Vliet, J.; Verburg, P.H.; Wu, W. GlobeLand30 shows little cropland area loss but greater fragmentation in China. Int. J. Appl. Earth Obs. Geoinf. 2018, 66, 37-45. [CrossRef]

3. Seto, K.C.; Güneralp, B.; Hutyra, L.R. Global forecasts of urban expansion to 2030 and direct impacts on biodiversity and carbon pools. Proc. Natl. Acad. Sci. USA 2012, 109, 16083-16088. [CrossRef]

4. Akpalu, W.; Stage, J. Connectivity at a cost: Economic dynamics of restoring habitat connectivity. Nat. Resour. Model. 2021, 34, 12294. [CrossRef]

5. Hanski, I. Habitat Loss, the Dynamics of Biodiversity, and a Perspective on Conservation. Ambio 2011, 40, 248-255. [CrossRef] [PubMed]

6. Baloch, M.A.; Zhang, J.; Iqbal, K.; Iqbal, Z. The effect of financial development on ecological footprint in BRI countries: Evidence from panel data estimation. Environ. Sci. Pollut. Res. 2019, 26, 6199-6208. [CrossRef] [PubMed]

7. Charfeddine, L. The impact of energy consumption and economic development on Ecological Footprint and $\mathrm{CO}_{2}$ emissions: Evidence from a Markov Switching Equilibrium Correction Model. Energy Econ. 2017, 65, 355-374. [CrossRef]

8. Ouyang, J.Q.; Isaksson, C.; Schmidt, C.; Hutton, P.; Bonier, F.; Dominoni, D. A New Framework for Urban Ecology: An Integration of Proximate and Ultimate Responses to Anthropogenic Change. Integr. Comp. Biol. 2018, 58, 915-928. [CrossRef]

9. Bai, X.; Shi, P.; Liu, Y. Society: Realizing China's urban dream. Nature 2014, 509, 158. [CrossRef]

10. Fu, B.; Liang, D.; Lu, N. Landscape ecology: Coupling of pattern, process, and scale. Chin. Geogr. Sci. 2011, 21, 385-391. [CrossRef]

11. Beier, P.; Spencer, W.; Baldwin, R.F.; McRae, B.H. Toward Best Practices for Developing Regional Connectivity Maps. Conserv. Biol. 2011, 25, 879-892. [CrossRef]

12. Modica, G.; Praticò, S.; Laudari, L.; Ledda, A.; Di Fazio, S.; De Montis, A. Implementation of multispecies ecological networks at the regional scale: Analysis and multi-temporal assessment. J. Environ. Manag. 2021, 289, 112494. [CrossRef]

13. Cho, S.-H.; Poudyal, N.; Lambert, D.M. Estimating spatially varying effects of urban growth boundaries on land development and land value. Land Use Policy 2008, 25, 320-329. [CrossRef]

14. Esbah, H.; Cook, E.A.; Ewan, J. Effects of Increasing Urbanization on the Ecological Integrity of Open Space Preserves. Environ. Manag. 2009, 43, 846-862. [CrossRef]

15. Benedict, M.A.; McMahon, E.T. Green infrastructure: Smart conservation for the 21st century. Renew. Res. J. 2002, $20,12-17$.

16. Fan, J. Theoretical innovation in optimization of protection and development of China's territorial space and coping strategy of 13th Five-Year Plan. Bull. Chin. Acad. Sci. 2016, 31, 1-12.

17. Yu, K. Security patterns and surface model in landscape ecological planning. Landsc. Urban Plan. 1996, 36, 1-17. [CrossRef]

18. Ma, K.; Fu, B.; Li, X.; Guan, W. The regional pattern for ecological security (RPES): The concept and theoretical basis. Acta Ecol. Sin. 2004, 24, 761-768.

19. He, C.; Liu, Z.; Tian, J.; Ma, Q. Urban expansion dynamics and natural habitat loss in China: A multiscale landscape perspective. Glob. Chang. Biol. 2014, 20, 2886-2902. [CrossRef] [PubMed]

20. Peng, J.; Yang, Y.; Liu, Y.; Hu, Y.; Du, Y.; Meersmans, J.; Qiu, S. Linking ecosystem services and circuit theory to identify ecological security patterns. Sci. Total. Environ. 2018, 644, 781-790. [CrossRef] [PubMed]

21. Zhang, L.; Peng, J.; Liu, Y.; Wu, J. Coupling ecosystem services supply and human ecological demand to identify landscape ecological security pattern: A case study in Beijing-Tianjin-Hebei region, China. Urban Ecosyst. 2016, 20, 701-714. [CrossRef] 
22. Jiang, H.; Peng, J.; Dong, J.; Zhang, Z.; Xu, Z.; Meersmans, J. Linking ecological background and demand to identify ecological security patterns across the Guangdong-Hong Kong-Macao Greater Bay Area in China. Landsc. Ecol. 2021, 36, 2135-2150. [CrossRef]

23. Tang, Y.; Gao, C.; Wu, X. Urban Ecological Corridor Network Construction: An Integration of the Least Cost Path Model and the InVEST Model. ISPRS Int. J. Geo-Inf. 2020, 9, 33. [CrossRef]

24. Dong, R.; Zhang, X.; Li, H. Constructing the Ecological Security Pattern for Sponge City: A Case Study in Zhengzhou, China. Water 2019, 11, 284. [CrossRef]

25. Yang, T.R.; Kuang, W.H.; Liu, W.D.; Liu, A.L.; Pan, T. Optimizing the layout of eco-spatial structure in Guanzhong urban agglomeration based on the ecological security pattern. Geogr. Res. 2017, 36, 441-452. [CrossRef]

26. Pascual-Hortal, L.; Saura, S. Comparison and development of new graph-based landscape connectivity indices: Towards the priorization of habitat patches and corridors for conservation. Landsc. Ecol. 2006, 21, 959-967. [CrossRef]

27. Gao, Y.; Ma, L.; Liu, J.; Zhuang, Z.; Huang, Q.; Li, M. Constructing Ecological Networks Based on Habitat Quality Assessment: A Case Study of Changzhou, China. Sci. Rep. 2017, 7, srep46073. [CrossRef] [PubMed]

28. Li, F.; Ye, Y.; Song, B.; Wang, R. Evaluation of urban suitable ecological land based on the minimum cumulative resistance model: A case study from Changzhou, China. Ecol. Model. 2015, 318, 194-203. [CrossRef]

29. Gurrutxaga, M.; Lozano, P.J.; del Barrio, G. GIS-based approach for incorporating the connectivity of ecological networks into regional planning. J. Nat. Conserv. 2010, 18, 318-326. [CrossRef]

30. Carvalho, F.; Carvalho, R.; Mira, A.; Beja, P. Assessing landscape functional connectivity in a forest carnivore using path selection functions. Landsc. Ecol. 2016, 31, 1021-1036. [CrossRef]

31. Graves, T.A.; Chandler, R.B.; Royle, J.; Beier, P.; Kendall, K.C. Estimating landscape resistance to dispersal. Landsc. Ecol. 2014, 29, 1201-1211. [CrossRef]

32. Kang, J.; Zhang, X.; Zhu, X.; Zhang, B. Ecological security pattern: A new idea for balancing regional development and ecological protection. A case study of the Jiaodong Peninsula, China. Glob. Ecol. Conserv. 2021, 26, e01472. [CrossRef]

33. Peng, J.; Zhao, H.; Liu, Y. Urban ecological corridors construction: A review. Acta Ecol. Sin. 2017, 37, 23-30. [CrossRef]

34. Belote, R.T.; Dietz, M.S.; McRae, B.H.; Theobald, D.M.; McClure, M.L.; Irwin, G.H.; McKinley, P.S.; Gage, J.A.; Aplet, G.H. Identifying Corridors among Large Protected Areas in the United States. PLoS ONE 2016, 11, e0154223. [CrossRef]

35. Wang, D.; Chen, J.; Zhang, L.; Sun, Z.; Wang, X.; Zhang, X.; Zhang, W. Establishing an ecological security pattern for urban agglomeration, taking ecosystem services and human interference factors into consideration. Peer] 2019, 7, e7306. [CrossRef]

36. Huang, J.; Hu, Y.; Zheng, F. Research on recognition and protection of ecological security patterns based on circuit theory: A case study of Jinan City. Environ. Sci. Pollut. Res. 2020, 27, 12414-12427. [CrossRef] [PubMed]

37. Keeley, A.T.H.; Beier, P.; Gagnon, J.W. Estimating landscape resistance from habitat suitability: Effects of data source and nonlinearities. Landsc. Ecol. 2016, 31, 2151-2162. [CrossRef]

38. Kong, F.; Yin, H.; Nakagoshi, N.; Zong, Y. Urban green space network development for biodiversity conservation: Identification based on graph theory and gravity modeling. Landsc. Urban Plan. 2010, 95, 16-27. [CrossRef]

39. Pickett, S.T.A.; Cadenasso, M.L.; Rosi, E.; Belt, K.T.; Groffman, P.M.; Grove, J.M.; Irwin, E.G.; Kaushal, S.S.; LaDeau, S.; Nilon, C.H.; et al. Dynamic heterogeneity: A framework to promote ecological integration and hypothesis generation in urban systems. Urban Ecosyst. 2017, 20, 1-14. [CrossRef]

40. Zhu, K.-W.; Chen, Y.-C.; Zhang, S.; Yang, Z.-M.; Huang, L.; Lei, B.; Li, L.; Zhou, Z.-B.; Xiong, H.-L.; Li, X.-X. Identification and prevention of agricultural non-point source pollution risk based on the minimum cumulative resistance model. Glob. Ecol. Conserv. 2020, 23, e01149. [CrossRef]

41. Peng, J.; Zhao, M.; Guo, X.; Pan, Y.; Liu, Y. Spatial-temporal dynamics and associated driving forces of urban ecological land: A case study in Shenzhen City, China. Habitat Int. 2017, 60, 81-90. [CrossRef]

42. Li, S.; Yang, B. Introducing a new method for assessing spatially explicit processes of landscape fragmentation. Ecol. Indic. 2015, 56, 116-124. [CrossRef]

43. Shi, P.; Yu, D. Assessing urban environmental resources and services of Shenzhen, China: A landscape-based approach for urban planning and sustainability. Landsc. Urban Plan. 2014, 125, 290-297. [CrossRef]

44. Peng, J.; Pan, Y.; Liu, Y.; Zhao, H.; Wang, Y. Linking ecological degradation risk to identify ecological security patterns in a rapidly urbanizing landscape. Habitat Int. 2018, 71, 110-124. [CrossRef]

45. Yu, D.; Liu, Y.; Xun, B.; Shao, H. Measuring Landscape Connectivity in a Urban Area for Biological Conservation. Clean Soil Air Water 2014, 43, 605-613. [CrossRef]

46. Li, M.; Liang, D.; Xia, J.; Song, J.; Cheng, D.; Wu, J.; Cao, Y.; Sun, H.; Li, Q. Evaluation of water conservation function of Danjiang River Basin in Qinling Mountains, China based on InVEST model. J. Environ. Manag. 2021, 286, 112212. [CrossRef]

47. Sharp, R.; Tallis, H.T.; Ricketts, T.; Guerry, A.D.; Wood, S.A.; Chapin-Kramer, R.; Nelson, E.; Ennaanay, D.; Wolny, S.; Olwero, N.; et al. InVEST 3.2.0 User's Guide; The Natural Capital Project, Stanford University, University of Minnesota, The Nature Conservancy, and World Wildlife Fund: Stanford, CA, USA, 2015.

48. Hao, Y.; Zhang, N.; Du, Y.J.; Wang, Y.H.; Zheng, Y.D.; Zhang, C.C. Construction of ecological security pattern based on habitat quality in Tang County, Hebei, China. J. Appl. Ecol. 2019, 30, 1015-1024, (in Chinese with English abstract). [CrossRef]

49. Lin, Q.; Mao, J.; Wu, J.; Li, W.; Yang, J. Ecological Security Pattern Analysis Based on InVEST and Least-Cost Path Model: A Case Study of Dongguan Water Village. Sustainability 2016, 8, 172. [CrossRef] 
50. Knaapen, J.P.; Scheffer, M.; Harms, B. Estimating habitat isolation in landscape planning. Landsc. Urban Plan. 1992, $23,1-16$. [CrossRef]

51. Yang, S.; Zou, C.; Shen, W.; Shen, R.; Xu, D. Construction of ecological security patterns based on ecological red line: A case study of Jiangxi Province. Chinese J. Ecol. 2016, 35, 250, (in Chinese with English abstract).

52. Luo, Y.; Wu, J.; Wang, X.; Peng, J. Using stepping-stone theory to evaluate the maintenance of landscape connectivity under China's ecological control line policy. J. Clean. Prod. 2021, 296, 126356. [CrossRef]

53. Fichera, C.R.; Laudari, L.; Modica, G. Application, validation and comparison in different geographical contexts of an integrated model for the design of ecological networks. J. Agric. Eng. 2015, 46, 52. [CrossRef]

54. Yang, Z.G.; Jiang, Z.Y.; Guo, C.X.; Yang, X.J.; Xu, X.J.; Li, X.; Hu, Z.M.; Zhou, H.Y. Construction of ecological network using morphological spatial pattern analysis and minimal cumulative resistance models in Guangzhou City, China. Chin. J. Appl. Ecol. 2018, 29, 3367-3376, (in Chinese with English abstract). [CrossRef]

55. Stauffer, F.; Best, L.B. Habitat Selection by Birds of Riparian Communities: Evaluating Effects of Habitat Alterations. J. Wildl. Manag. 1980, 44. [CrossRef]

56. Bueno, J.A.; Tsihrintzis, V.A.; Alvarez, L. South Florida greenways: A conceptual framework for the ecological reconnectivity of the region. Landsc. Urban Plan. 1995, 33, 247-266. [CrossRef]

57. Bai, L.; Xiu, C.; Feng, X.; Liu, D. Influence of urbanization on regional habitat quality:a case study of Changchun City. Habitat Int. 2019, 93, 102042. [CrossRef]

58. Housing and Urban-Rural Development Department of Guangdong Province in PRC. Green Pearl River Delta road network master plan outline. Superv. Test Cost Constr. 2010, 3, 10-69, (in Chinese with English Abstract).

59. Dai, L.; Liu, Y.; Luo, X. Integrating the MCR and DOI models to construct an ecological security network for the urban agglomeration around Poyang Lake, China. Sci. Total. Environ. 2021, 754, 141868. [CrossRef]

60. Yu, Q.; Yue, D.; Wang, J.; Zhang, Q.; Li, Y.; Yu, Y.; Chen, J.; Li, N. The optimization of urban ecological infrastructure network based on the changes of county landscape patterns: A typical case study of ecological fragile zone located at Deng Kou (Inner Mongolia). J. Clean. Prod. 2017, 163, S54-S67. [CrossRef]

61. Wilson, M.A.; Howarth, R. Discourse-based valuation of ecosystem services: Establishing fair outcomes through group deliberation. Ecol. Econ. 2002, 41, 431-443. [CrossRef]

62. Zhu, Q.; Yu, K.J.; Li, D.H. The width of ecological corridor in landscape planning. Acta Ecol. Sin. 2005, 25, 2406-2412, (in Chinese with English abstract). [CrossRef]

63. Yeung, C.; Yang, M.-S. Spatial variation in habitat quality for juvenile flatfish in the southeastern Bering Sea and its implications for productivity in a warming ecosystem. J. Sea Res. 2018, 139, 62-72. [CrossRef]

64. General Office of the People's Government of Shenzhen Municipality. Ecological City Construction Plan of Shenzhen. 2007. Available online: http://www.sz.gov.cn/zwgk/zfxxgk/zfwj/szfwj/content/post_6577266.html (accessed on 2 February 2021).

65. Ma, X.; Tao, J. Cross-border environmental governance in the Greater Pearl River Delta (GPRD). Int. J. Environ. Stud. 2010, 67, 127-136. [CrossRef]

66. Saura, S.; Bodin, Ö.; Fortin, M.J. EDITOR'S CHOICE: Stepping stones are crucial for species' long-distance dispersal and range expansion through habitat networks. J. Appl. Ecol. 2014, 51, 171-182. [CrossRef]

67. Urban Administration Office of the People's Government of Shenzhen Municipality (Urban Administration and Regulation of Shenzhen Municipality). Master Plan of National Forest City Construction of Shenzhen (2016-2025). 2017. Available online: http:/ / cgj.sz.gov.cn/zwgk/ghjh/fzgh/content/post_2127354.html (accessed on 2 February 2021). 